\title{
AGAMA DAN NEGARA \\ PERSPEKTIF FIQH SIYASAH
}

\author{
Lukman Arake \\ Sekolah Tinggi Agama Islam Negeri (STAIN) Watampone \\ Email: fawwazlukman@gmail.com
}

\begin{abstract}
Abstrak
Islam datang tidak hanya membawa ajaran akidah semata, tidak juga datang untuk mengatur perilaku manusia semata yang kemudian dijadikan dasar nilai dalam membangun kesepahaman di antara mereka. Akan tetapi Islam di samping datang membawa hal-hal yang disebutkan, juga membawa syariat dengan penuh kejelasan dan nilai-nilai keadilan. Syariat itulah yang kemudian mengatur kehidupan umat manusia secara keseluruhan. Selain mengatur semua bentuk hubungan manusia, Islam juga telah meletakkan banyak nilai-nilai serta prinsipprinsip yang bersifat umum guna dijadikan oleh manusia sebagai dasar dalam melakukan interaksinya dengan sesama. Karena Islam telah datang membawa berbagai macam aturan dan prinsip-prinsip hidup maka kemudian untuk mengimplementasikan semua itu dalam kehidupan nyata, umat Islam dituntut mendirikan negara agar semuanya dapat diatur dengan baik. Oleh sebab itu Islam kemudian disebut dengan risalah khalidah, dinan alamiyyan dan penutup semua risalah untuk umat manusia, bersifat menyeluruh sampai dunia berakhir. Semenjak Nabi SAW tinggal di Madinah bersama para sahabatnya, beliau menjadikan Madinah sebagai tanah airnya. Para sahabat memberikan kewenangan kepada Nabi untuk menjadi pemimipin di tengah-tengah mereka dengan menjadikan syariat Islam yang bersumber dari al-Qur'an dan hadis sebagai aturan yang harus dipatuhi oleh semua. Maka dari itu, nampak jelas bahwa Islam bukan hanya sekedar agama yang mengajarkan masalah akidah dan ibadah ritual semata, akan tetapi Islam adalah agama dan negara. Itulah sebabnya para ulama menyatakan bahwa syariat Islam diwahyukan oleh Allah kepada Nabi, tujuannya agar manusia dapat hidup bahagia tidak hanya di dunia, tetapi juga di akhirat.
\end{abstract}

\section{Kata Kunci : Islam, Agama, Negara}

\section{PENDAHULUAN}

\section{Pemisahan Antara Agama dan Negara}

Belakangan ini, masyarakat Indonesia diramaikan dengan isu hangat tentang pemisahan antara agama dan negara, sehingga ada yang berpendapat bahwa ulama tidak perlu terlibat dalam urusan politik, cukuplah mereka mengurusi urusan agama saja. Jika ditelaah lebih jauh, sesungguhnya pernyataan 
yang mengatakan adanya pemisahan antara agama dan negara merupakan salah satu prinsip yang telah dicetuskan oleh orang-orang Kristen Eropa. Prinsip pemisahan tersebut merupakan akibat dari perseteruan yang berkepanjangan antara pihak gereja di satu sisi dengan pihak penguasa di sisi lain. Beberapa dokumen dan penelitian mengungkap adanya gerakan rahasia yang dilakukan orang-orang Yahudi yang mendorong agar terjadi pemisahan antara agama dengan negara sekaligus memotivasi agar persoalan agama dijauhkan dari urusan politik sebagai langkah awal untuk melepaskan diri dari masyarakat "jiytu" yang terdiskriminasi menuju masyarakat yang memiliki hak yang sama dengan masyarakat lain terutama yang berkaitan dengan hak-hak politik, sosial dan kemasyarakatan. ${ }^{1}$

Munculnya gerakan pemisahan antara agama dan negara sesungguhnya dipengaruhi oleh banyak faktor termasuk faktor sejarah, faktor politik dan faktor agama. Dari tiga faktor yang disebutkan itu menurut sebagian pakar bahwa faktor politiklah yang mendominasi. Setelah Eropa mulai mengalami kemajuan baik di bidang ekonomi, sains, maupun di bidang politik mulailah bermunculan pemikirpemikir yang menyerukan pentingnya melakukan pemisahan antara urusan agama dengan urusan negara. Mereka menyatakan bahwa hal itu sangat penting untuk dilakukan dalam semua lini kehidupan, dalam semua kondisi, dan dalam semua agama. Akibat dari gerakan tersebut, sebagian orang Islam terpengaruh dengan pemikiran tersebut sehingga dengan terang-terangan mendakwakannya walaupun hal itu dianggap berseberangan dengan semangat dan nilai-nilai implisit ajaran Islam. $^{2}$

Cikal bakal munculnya gerakan pemisahan antara agama dan negara merupakan hasil pemikiran orang-orang Kristen Eropa akibat masa-masa suram yang berkepanjangan yang mereka alami. Karenanya, gerakan pemisahan antara agama dan negara telah memicu munculnya beberapa pertanyaan terkait dengan sejauhmana pemisahan itu terjadi. Apakah memang ada kemungkinan dalam sejarah kehidupan manusia, agama dan negara telah terjadi pemisahan secara

1 Faruq Abdussalam, Al-Ahzab al-Siyasiyah wal Faslu Baina Addini Wassiyasah, Maktabah Kalyub, Kairo, hlm. 4

${ }^{2}$ Faruq Abdussalam, Al-Ahzab al-siyasiyah....hlm. 4. 
mutlak dan menyeluruh? Apakah memang agama dan pengaruhnya terhadap kehidupan manusia dalam kurun masa tertentu betul-betul pernah terpisah dari kehidupan politik? Di negara mana di Eropa yang didiami oleh mayoritas Kristen dalam urusan politik tidak terpengaruh dengan doktrin akidah dan agama yang mereka yakini padahal mereka juga hidup berkelompok-kelompok? Apakah pemisahan agama dan negara telah pernah membuming dan mengkristal dalam kehidupan satu komunitas yang kemudian menjadi doktrin atau prinsip yang bersifat paten sehingga kemudian menjadi suatu teori ilmiah yang dipahami dan disepakati sehingga dapat dipelajari, diajarkan dan bahkan diaplikasikan? Atau jangan-jangan keduanya merupakan dua bentuk kekuasaan yang berimbang; dan itu tidak mungkin seperti kata orang bijak, dua pedang tidak mungkin dapat disatukan dalam satu sarung. Apakah para penggagas teori ini dapat dengan adil melakukan pembagian kekuasaan melindungi dan mencegah terjadinya hal-hal yang tidak diinginkan? Apakah rasional dalam perkembangan kehidupan manusia terdapat suatu hari dimana semua orang dalam satu negara sepakat mengingkari adanya semua akidah dan agama dengan berpegang teguh pada satu partai saja yang dengannya menolak hal-hal yang berbau agama? Dan yang terakhir, apakah boleh secara teori saja dikatakan adanya pemisahan antara agama dan negara sementara secara praktik tidak demikian?

Seperti yang telah disinggung bahwa pemisahan antara agama dan negara merupakan pemikiran yang dimunculkan oleh Kristen Eropa akibat kondisi dan perseteruan yang berkepanjangan antara pihak gereja dengan pihak penguasa terutama ketika Gereja membantai habis beberapa ulama mereka pada masa kebangkitan yang mereka lalui. Tetapi dari semua itu, yang paling menakutkan di masa modern ini ialah karena gerakan zionis dunia juga sempat mengadopsi teori tersebut untuk memudahkan orang-orang Yahudi keluar dari keterkungkungan akibat mereka dianggap sebagai masyarakat "jiyto" yang terisolasi dan sangat eksklusif. Atas nama HAM mereka kemudian berteriak menyuarakan pentingnya pemisahan antara agama dan negara agar mereka dapat menyamai yang lain terutama dalam hal sosial dan politik. Salah satu misi mereka adalah mendirikan "negara Yahudi" dengan adagium "bangsa pilihan Tuhan" (Sya'bullahi al- 
Mukhtar) setelah melenyapkan semua agama lain. Demikian salah satu misi terselubung "protokol Zionis". 3

Boleh jadi yang mendorong seseorang mengatakan adanya pemisahan agama dan negara karena adanya perkembangan dalam semua lini kehidupan semakin berkembang sehingga menuntut adanya spesialisasi khusus di masingmasing sektor. Islam sendiri tidak mempermasalahkan hal itu, tetapi yang menjadi masalah ialah apa memang rasional jika dikatakan bahwa berbagai macam spesialisasi yang dimaksud itu memang tidak ada keterkaitan antara satu dengan yang lain. Makna agama di dalam Islam jauh lebih luas cakupannya dibanding dengan cakupan politik. Politik dalam perspektif Islam tidak merespon pembolehan sesuatu yang diharamkan oleh agama. Apapun bentuk pembolehan itu termasuk kebijakan seorang penguasa bila bertentangan dengan nilai-nilai normatif agama akan dianggap tidak sah. Riba, zina, pelecehan seksual, monopoli, korupsi, dan semua yang diharamkan oleh agama tidak mungkin dapat dijustifikasi sebagai suatu nilai yang layak dipertahankan walau dilakukan atas dasar suka sama suka.

Sudah menjadi konvensi di dalam Islam bahwa antara shalat dan puasa tidak mungkin dapat dipisahkan, antara syiar agama dan suatu sistem politik. Oleh karenanya, di dalam Islam dinyatakan tidak boleh ada partai politik yang dibentuk untuk mengajak orang banyak untuk memisahkan antara agama dan negara. Di dalam Islam tidak diperkenankan adanya partai yang visi misinya membedakan antara persoalan ibadah dengan persoalan muamalah. Itulah mengapa di dalam sejarah Islam, sekte-sekte yang muncul misalnya Khawarij, Syiah dan kelompok ahlussunnah yang moderat walau mereka berbeda dalam masalah dosa besar dan dosa kecil, berbeda dalam hal tertentu lainnya yang mengakibatkan terjadinya perseteruan yang berkepanjangan, tetapi di lain sisi mereka semuanya sepakat bahwa agama Islam bersifat universal mencakup semua sendi kehidupan manusia.

Sangat jelas bahwa semua sekte yang ada di dalam Islam menyatakan penolakannya terhadap pemisahan antara agama dan negara. Karenanya sangat disayangkan bila di masa sekarang ini di beberapa negara yang mayoritas

\footnotetext{
${ }^{3}$ Faruq Abdussalam, Al-Ahzab al-Siyasiyah...., hlm.137.
} 
penduduknya muslim justru masih banyak terpengaruh dengan sistem politik yang dikembangkan oleh para penggiat sekularisme yang nota benenya lahir akibat perseteruan berkepanjangan yang terjadi di Eropa antara gereja dengan penguasa. Turki sebagai satu negara yang berpenduduk mayoritas muslim seringkali dijadikan contoh sebagai negara sekuler di masa sekarang. Seperti yang dikutip Faruq Abdussalam bahwa dalam undang-undang Republik Turki yang dikeluarkan pada tanggal 9 Juli tahun 1961 di antaranya menyatakan: ${ }^{4}$ Pertama, Republik Turki, adalah negara yang bersifat nasionalis, demokratis, sekularis, dan sosialis". Kedua, "Sebaiknya semua aturan, program, dan aktivitas partai politik yang ada sesuai dengan prinsip-prinsip: republik, demokrasi, dan sekuler”. Ketiga, “Tidak boleh seseorang dipaksa untuk melakukan ritual ibadah, dipaksa untuk menghadiri suatu upacara, termasuk upacara keagamaan, dipaksa untuk menyatakan keyakinannya, dan pendapatnya tentang agama; begitu juga tidak boleh seseorang dikritik karena keyakinannya atau pendapatnya tentang masalah keagamaan". Keempat, "Tidak boleh berdasar pada pendidikan agama untuk mendukung aturan atau sistem negara baik terkait dengan masalah sosial, ekonomi, politik, atau perundang-undangan. Semua yang menyalahi ketentuan tersebut, atau mendorong orang lain menyalahinya akan dihukum sesuai dengan undang-undang".

Dalam sebuah artikel yang ditulis oleh Prof. Nasaruddin Umar ${ }^{5}$ disebutkan bahwa memang agak sulit mendefinisikan sebuah negara sekuler kalau yang dimaksud negara sekuler itu adalah negara yang memberikan pemisahan pengaturan agama dan negara. Sulit menemukan sebuah negara di kolom langit ini yang terbebas sama sekali dari praktek keagamaan di dalam penyelenggaraan kenegaraan. Sama sulitnya menemukan negara yang terbebas sama sekali dari unsur-unsur sekuler. Sesekuler apapun sebuah negara tetap saja praktek keagamaan selalu muncul dalam penyelenggaraan kenegaraan. Minimal pengambilan sumpah pejabat dilakukan sumpah menurut ajaran agama yang dianut pejabat yang bersangkutan. Hampir semua lagu kebangsaan di negara-

\footnotetext{
${ }^{4}$ Faruq Abdussalam, Al-Ahzab al-Siyasiyah....hlm.138.

${ }^{5}$ Beliau adalah mantan wakil menteri agama RI., dan sekarang diserahi amanah sebagai Imam Besar Mesjid Istiqlal Jakarta.
} 
negara Eropa dan Amerika menyebut nama Tuhan. Amerika Serikat sendiri masih terus mewajibkan lagu-lagu pujian terhadap Tuhan pada murid-murid sekolah.

Namun jika yang dimaksud negara sekuler ialah negara yang menghindari kerancuan antara negara dan agama lalu urusan pemerintahan diberikan kepada para pemerintah khususnya kepada pihak eksekutif, sementara agama diserahkan pengaturannya kepada pemimpin agama, maka negara-negara seperti ini dapat ditemukan di mana-mana, bukan saja di dalam negara-nagara mayoritas penduduknya non-muslim, seperti di Eropa dan Amerika, tatapi juga di negaranegara muslim, seperti Turki yang semenjak dipimpin oleh presiden pertamanya, Mustafa Kemal Attaturk (1881-1930) sampai sekarang tetap mengklaim negaranya sebagai negara sekuler. Turki sering dijadikan contoh sebagai negara sekuler karena memisahkan kewenangan dan peran negara dan agama di dalam masyarakat, meskipun kenyataannya kekuatan agama di dalam masyarakat masih tetap kuat. Apalagi selama dekade terakhir ini, "islamisasi" semakin menjadi fenomena di kampus-kampus. Ini suatu bukti bahwa agama dan masyarakat tidak bisa dipisahkan. Sesekuler apapun sebuah negara jika rasa keagamaan tumbuh subur di dalamnya pasti tidak akan menjadi negara sekuler mutlak. Apalagi Turki yang dikenal sebagai negara sejuta mesjid.

Agama dalam suatu negara tidak selamanya tampil sebagai faktor independen. Agama sering tampil sangat dependen terhadap negara dan bahkan agama terkadang menjadi alat legitimasi para penguasa, tentu demikian pula sebaliknya. Persoalan akan menjadi lebih rumit jika persepsi "negara" yang dianut oleh suatu bangsa mengikuti pola Hegel (1776-1831) yang menganggap negara sebagai penjelmaan jiwa mutlak, dan dalam upaya mencapai tujuannya tidak peduli harus mengorbankan maslahat-maslahat pribadi. Seolah-olah negara mempunyai bahasa sendiri, budipekerti sendiri, pikiran sendiri, bahkan nilai-nilai agama sendiri.

Bagi Hegel, negara adalah tujuan, bukan cara. Pribadi, keluarga dan masyarakatlah yang menjadi cara. Atas dasar ini Hegel menyusun falsafah nasionalisme, dimana loyalitas seseorang adalah untuk negara nasional yang tersusun di atas kondisi obyektif suatu bangsa. Rasa nasionalisme lebih kuat dari 
rasa cinta kepada kemerdekaan. Nasionalisme mengadopsi apa yang disebut dengan inner werkende Krafte, 'kekuatan dalam' yang bisa menggilas para penentangnya. Pola dialektik Hegel lebih mengedepankan principle of negation, ketimbang principle of identity, yang mengedepankan titik temu di antara perbedaan yang ada. Celakanya kalau konsep negara dan nasionalisme semacam ini berhadapan langsung dengan Islam, agama yang secara khusus memiliki konsep syari'ah, hukum-hukum yang mengatur mulai dari isi hati setiap orang sampai kepada masyarakat dan negara. Ketegangan konseptual dalam hal ini sulit dihindari karena negara dan agama berkompetisi memperebutkan loyalitas indifidu dan masyarakat.

Pemandangan ini sebenarnya pernah terjadi di Indonesia, terutama dalam akhir paruh pertama rezim Orde Baru, ketika Pak Ali Murtopo tampil sebagai arsitek politik Soeharto. Dalam masa ini, membicarakan eksistensi syari'ah bagaikan penuh dengan ranjau. Orang-orang harus ekstra hati-hati karena salah sedikit terjebak dalam perangkap isu SARA yang selalu dibayangi dengan akronim menakutkan, seperti subversif, fundamentalisme, komando jihad, ekstrim kanan, black list, dan berbagai ancaman lainnya dari Kopkamtib, suatu institusi yang mempunyai kewenangan besar untuk menangkap orang tanpa melalui proses hukum normal.

\section{PEMBAHASAN}

\section{A. Relevansi Agama dan Negara}

Agama atau addin oleh para pakar dimaknai sebagai kumpulan kewajiban manusia terhadap Allah, kewajiban terhadap orang banyak, dan kewajiban terhadap dirinya sendiri. Sebagian yang lain mengatakan bahwa agama ialah sejumlah keyakinan (akaid) dan wasiat yang mengarahkan semua manusia kepada bagaimana berperilaku terhadap Allah, terhadap sesama, dan terhadap diri sendiri. Imam Assaharstani menyebutkan dalam karya monumentalnya al-milal wannihal bahwa agama ialah ketaatan dan kepatuhan; dan terkadang juga dimaknai sebagai 
perhitungan dan balasan. ${ }^{6}$ Ibnul Kamal mengatakan bahwa agama adalah hukum Allah yang mengajak orang-orang yang berakal kepada kebaikan sesuai dengan kehendak mereka sendiri. Selain itu ada juga berpendapat bahwa agama adalah hukum Allah yang diberlakukan untuk semua orang yang berakal menuju kebaikan sesuai dengan kehendak mereka sendiri. ${ }^{7}$

Sedangkan kata addin dalam al-Qur'an memiliki makna yang berbedabeda sesuai dengan redaksi ayat yang ada. Addin terkadang bermakna "balasan" seperti firman Allah:

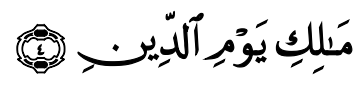

"Yang menguasai di hari Pembalasan".(QS.al-Fatihah: 4).

Kata addin juga terkadang diartikan sebagai "dasar" atau "keyakinankeyakinan" seperti firman Allah:
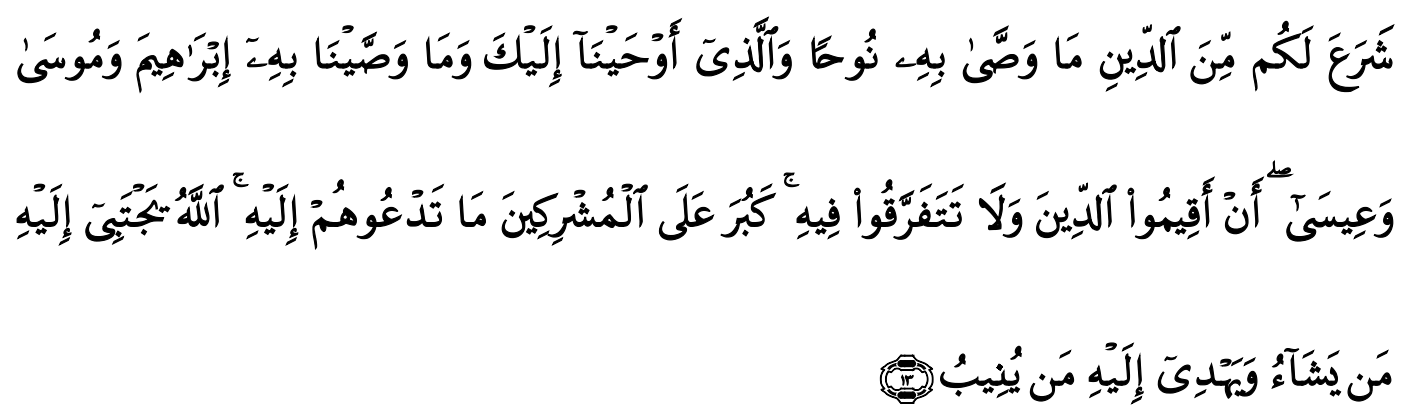

"Dia telah mensyari'atkan bagi kamu tentang agama apa yang telah diwasiatkan-Nya kepada Nuh dan apa yang telah kami wahyukan kepadamu dan apa yang telah kami wasiatkan kepada Ibrahim, Musa dan Isa yaitu: tegakkanlah agama, dan janganlah kamu berpecah belah tentangnya. Amat berat bagi orang-orang musyrik agama yang kamu seru mereka kepadanya. Allah menarik kepada agama itu orang yang dikehendaki-Nya dan memberi petunjuk kepada (agama)-Nya orang yang kembali (kepada-Nya)”. (QS.Assyura: 13).

\footnotetext{
Kairo, hlm.7.

${ }^{6}$ Muhammad Yusuf Musa, 1995, al-Islam Wahajatul Insan Ilaihi, Wizarah al-Aukaf,

${ }^{7}$ Muhammad Azzabidi, Taj al-Arus, Dar Assadar, Bairut, Jld. IX. .hlm.208.
} 
Addin di dalam al-Qur'an juga terkadang dimaknai untuk mengungkapkan “agama Islam” secara spesifik seperti firman Allah:

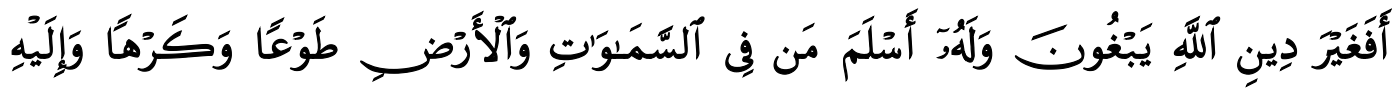

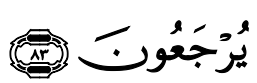

"Maka apakah mereka mencari agama yang lain dari agama Allah, padahal kepada-Nya-lah menyerahkan diri segala apa yang di langit dan di bumi, baik dengan suka maupun terpaksa dan hanya kepada Allahlah mereka dikembalikan”.(QS. Ali Imran: 83).

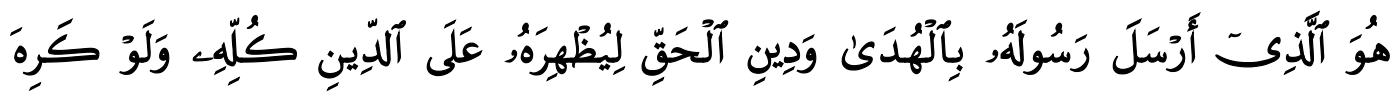

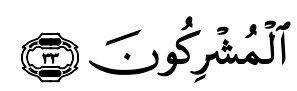

"Dialah yang Telah mengutus RasulNya (dengan membawa) petunjuk (AlQuran) dan agama yang benar untuk dimenangkanNya atas segala agama, walaupun orang-orang musyrikin tidak menyukai”.(QS.Attaubah: 33).

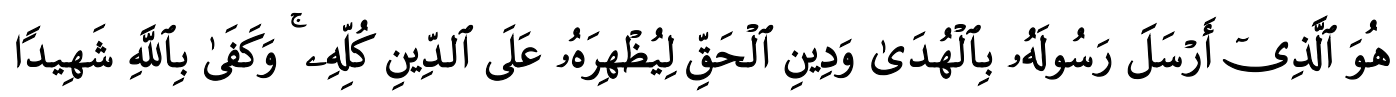

"Dia-lah yang mengutus rasul-Nya dengan membawa petunjuk dan agama yang hak agar dimenangkan-Nya terhadap semua agama. dan cukuplah Allah sebagai saksi”.(QS.al-Fath: 28).

Addin juga di dalam al-Qur'an terkadang bermakna sebagai suatu keyakinan yang dianut oleh suatu kelompok masyarakat walaupun pada kenyataannya keyakinan tersebut tidak benar. Allah berfirman:

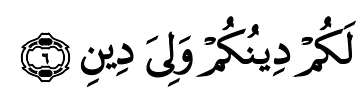

“Untukmu agamamu, dan untukkulah, agamaku”.(QS.al-Kafirun: 6). 
Islam datang tidak hanya membawa ajaran akidah semata, tidak juga datang untuk mengatur perilaku manusia semata yang kemudian dijadikan dasar nilai dalam membangun kesepahaman di antara mereka. Akan tetapi Islam di samping datang membawa hal-hal yang disebutkan, juga membawa syariat dengan penuh kejelasan dan nilai-nilai keadilan. Syariat itulah yang kemudian mengatur kehidupan umat manusia secara keseluruhan termasuk bagaimana semestinya berperilaku terhadap dirinya sendiri, hubungan dirinya dengan penciptanya, berperilaku terhadap keluarganya, berperilaku terhadap masyarakatnya; dan bahkan juga bagaimana negaranya berperilaku terhadap negara lain. Dengan nilai-nilai inilah, Islam kemudian tampil berbeda dengan agama lain. $^{8}$

Selain mengatur semua bentuk hubungan manusia, Islam juga telah meletakkan banyak nilai-nilai serta prinsip-prinsip yang bersifat umum guna dijadikan oleh manusia sebagai dasar dalam melakukan interaksinya dengan sesama. Karena Islam telah datang membawa berbagai macam aturan dan prinsipprinsip hidup maka kemudian untuk mengimplementasikan semua itu dalam kehidupan nyata, umat Islam dituntut mendirikan negara agar semuanya dapat diatur dengan baik. Manusia diatur oleh Islam sejak ia masih dalam kandungan sampai ia dimasukkan ke liang kubur; dan bahkan masih akan diatur di alam lain selain alam dunia. Oleh sebab itu Islam kemudian disebut dengan risalah khalidah, dinan alamiyyan dan penutup semua risalah untuk umat manusia, bersifat menyeluruh sampai dunia berakhir. Dalam al-Qur'an Allah SWT mempertegas kepada Nabi bahwa ia diutus untuk seluruh manusia. Allah berfirman:

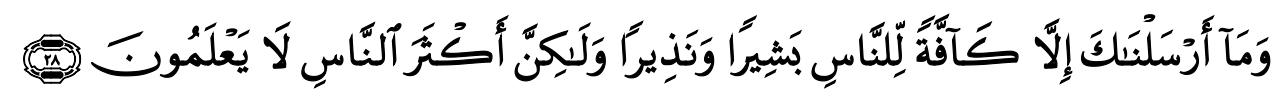

"Dan kami tidak mengutus kamu, melainkan kepada umat manusia seluruhnya sebagai pembawa berita gembira dan sebagai pemberi peringatan, tetapi kebanyakan manusia tiada mengetahui”.(QS. Saba’: 28).

${ }^{8}$ Muhammad Bahauddin Salim, al-Islam, Addin, Addaulah, (Kairo: Kitab al-Jumhuriyah), Hal.35. 


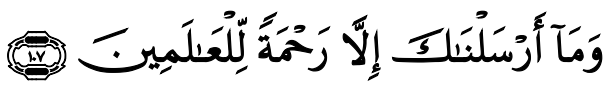

"Dan tiadalah kami mengutus kamu, melainkan untuk (menjadi) rahmat bagi semesta alam”. (QS. al-Anbiya: 107).

Allah juga menegaskan kepada Nabi agar menyampaikan kepada seluruh manusia bahwa dirinya diutus kepada semuanya tanpa kecuali. Allah berfirman:

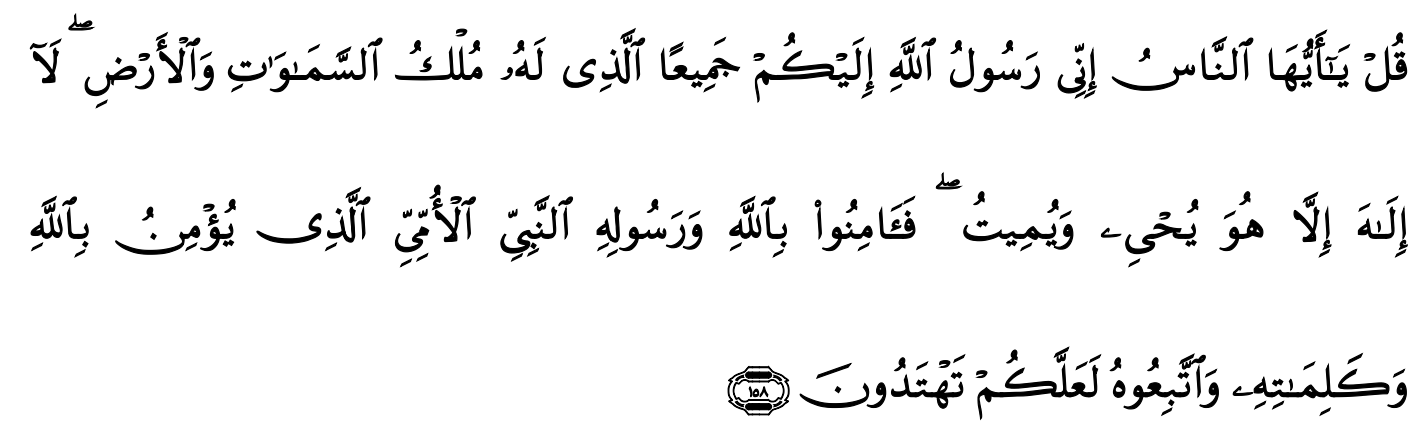

"Katakanlah: "Hai manusia Sesungguhnya Aku adalah utusan Allah kepadamu semua, yaitu Allah yang mempunyai kerajaan langit dan bumi; tidak ada Tuhan (yang berhak disembah) selain Dia, yang menghidupkan dan mematikan, Maka berimanlah kamu kepada Allah dan Rasul-Nya, Nabi yang ummi yang beriman kepada Allah dan kepada kalimat-kalimatNya (kitab-kitab-Nya) dan ikutilah Dia, supaya kamu mendapat petunjuk".(QS. al-A'raf: 158).

Sementara itu negara dalam perspektif agama sering dimaknai sebagai pengaturan yang memberikan jaminan kepada seluruh elemen masyarakat untuk melakukan interaksi antara satu dengan yang lain sesuai dengan aturan yang disepakati oleh mereka sendiri dengan tujuan saling menguntungkan dan tidak saling merugikan. ${ }^{9}$ Sedangkan pengertian negara menurut para pakar tata negara konvensional adalah sekelompok masyarakat yang secara indevenden hidup secara terus menerus dalam suatu wilayah tertentu dimana di antara mereka ada yang menjadi pemimpin dan ada pula yang dipimpin. ${ }^{10}$ Sebagian lagi mengatakan bahwa negara ialah sekelompok masyarakat yang hidup secara terus menerus

\footnotetext{
${ }^{9}$ Muhammad al-Bahiy, 1980, Addin wa Addaulah, Maktabah Wahbah, Kairo, hlm. 395.

10 Ismail Badawi, 1994, Nazariyyah Addaulah, Dar Annahdah al-Arabiyah, Kairo,
} hlm..36. 
dalam suatu wilayah tertentu yang dikuasai oleh suatu lembaga pemerintahan yang memiliki kedaulatan. ${ }^{11}$

Bila memperhatikan secara seksama penjelasan para pakar hukum tata negara terkait penjelasan mereka tentang makna dan maksud daripada negara maka dapat disimpulkan bahwa dalam mendirikan sebuah negara tidak terlepas dari beberapa unsur pokok yakni adanya masyarakat yang mendiami suatu daerah atau kawasan tertentu, adanya seorang pemimpin yang memiliki otoritas untuk mengatur, adanya aturan hukum dimana semuanya patuh terhadap hukum yang dimaksud, dan yang keempat ialah adanya kemandirian dan independensi politik yang dengannya masyarakat mampu mengurus dirinya sendiri tanpa harus mengikut kepada negara lain. Berdirinya suatu negara sangat ditentukan oleh adanya sekelompok masyarakat, adanya wilayah yang didiami secara terus menerus, dan adanya lembaga pemerintahan yang memiliki kedaulatan untuk mengatur semua urusan masyarakat serta menguasai semua wilayahnya tanpa intervensi dari luar.

Kalau unsur-unsur tersebut menurut para ahli hukum tata negara konvensional mesti terpenuhi dalam mendirikan suatu negara, maka sesungguhnya unsur-unsur yang disebutkan itu juga telah ada dan telah terimplementasi dengan baik pada masa Nabi ketika beliau berada di Madinah. Unsur-unsur yang disebutkan di atas telah banyak disinggung baik dalam alQur'an maupun dalam hadis Nabi SAW yang kemudian menjadi bagian yang tidak terpisahkan dari kehidupan beliau bersama sahabatnya begitu pula generasi yang datang setelahnya. Semenjak Nabi SAW tinggal di Madinah bersama para sahabatnya, beliau menjadikan Madinah sebagai tanah airnya. Para sahabat memberikan kewenangan kepada Nabi untuk menjadi pemimipin di tengah-tengah mereka dengan menjadikan syariat Islam yang bersumber dari al-Qur'an dan hadis sebagai aturan yang harus dipatuhi oleh semua. Maka dari itu, nampak jelas bahwa Islam bukan hanya sekedar agama yang mengajarkan masalah akidah dan ibadah ritual semata, akan tetapi Islam adalah agama dan negara. Itulah sebabnya para ulama menyatakan bahwa syariat Islam diwahyukan oleh Allah kepada Nabi,

\footnotetext{
${ }^{11}$ Muhammad Allafi, Nazarat fi Ahkami al-Harbi wa Assilmi, Dar Iqra; Libia, hlm. 26.
} 
tujuannya agar manusia dapat hidup bahagia tidak hanya di dunia, tetapi juga di akhirat.

Islam sebagai agama memiliki karakteristiknya sendiri yang membedakan dirinya dengan agama lain. Karakteristik itulah dalam pandangan sebagian cendekiawan Muslim kontemporer yang harus menjadi acuan dalam setiap mendakwakan Islam kepada orang lain. Karakteristik yang dimaksud ialah bahwa Islam adalah agama yang mengajarkan persatuan, agama fitrah, agama rasional, agama yang mengajarkan kebebasan, agama yang mengajarkan persamaan hak dan kewajiban, serta agama yang mengajarkan nilai-nilai kemanusiaan. ${ }^{12}$

Wilayah negara yang ada pada masa Nabi sudah mulai meluas. Semua itu dapat tercapai karena Islam sebagai agama yang penuh dengan nilai-nilai humanisme, di samping karena penggunakan kata ummat (nation) dalam alQur'an yang berarti thaifah atau fi'ah (kelompok) seperti firman Allah dalam alQur'an:

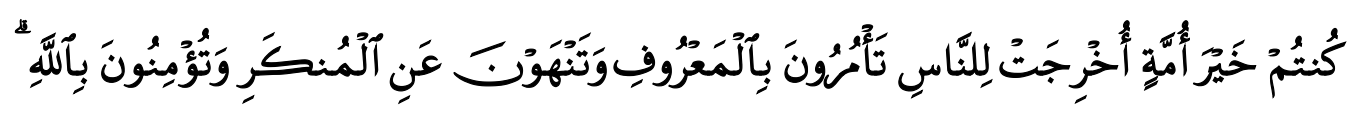

"Kamu adalah umat yang terbaik yang dilahirkan untuk manusia, menyuruh kepada yang máruf, dan mencegah dari yang munkar, dan beriman kepada Allah". (Qs.Ali Imran/110)

Menurut al-Maududi bahwa orang yang merenungi ayat di atas akan mengerti bahwa negara yang diinginkan oleh al-Qur'an tidak hanya fokus pada masalah yang bersifat negatif, tetapi juga fokus pada hal-hal yang bersifat positif. Artinya tujuan negara bukan hanya untuk mencegah manusia untuk saling memusuhi, atau menjaga kebebasan setiap individu termasuk menjaga stabilitas negara, tetapi juga negara hadir untuk membumikan nilai-nilai keadilan sosial sesuai petunjuk al-Qur'an misalnya menebar kebajikan dan mencegah kemungkaran. ${ }^{13}$

\footnotetext{
${ }^{12}$ Muhammad Yusuf Musa, al-Islam wahajatu al-Insan Ilaihi...hlm. 18-36.

${ }_{13}$ Abul A'la al-Maududi, 1985, Nazariyah al-Islam wa Hadyuhu fi Assiyasah Walqanun Waddustur, Addar Assaudiyah, Jeddah, hlm .46.
} 
Karena Islam adalah agama yang sarat dengan nilai-nilai kemanusiaan maka Allah menjadikannya sebagai risalah terakhir untuk dunia. Nabi dalam membangun masyarakat, selalu mengajarkan nilai-nilai tersebut agar dijadikan sebagai pegangan dalam berperilaku dan beraktivitas dalam setiap waktu dan tempat. Dengan demikian, Islam bukan hanya sebatas akidah agama saja, atau sistem akhlak saja, akan tetapi Islam adalah agama dan negara. ${ }^{14}$

Dalam literatur Islam klasik banyak dijelaskan bahwa agama dan negara adalah dua hal yang tidak mungkin dipisahkan, karena agama dijadikan sebagai dasar dalam menjalankan roda pemerintahan di dalam suatu negara baik yang berkaitan dengan masalah rakyat secara umum maupun masalah pemerintahan sehingga pada akhirnya Islam dinyatakan sebagai dinun wadaulah, agama dan negara.

Di dalam Islam, teori tentang negara merupakan pemikiran yang berdasar pada kaedah-kaedah agama yang bersumber dari al-Qur'an dan hadis Nabi. Islam sangat memperhatikan masalah pemerintahan dan tatanan politik yang baik seperti halnya Islam memberikan perhatian penuh terhadap masalah ekonomi dan masalah finansial lainnya sehingga kemudian ditegaskan bahwa Islam adalah akidah dan syariat, agama dan negara, karena memang sepanjang sejarah kenyataan hidup dan kehidupan orang-orang Islam menunjukkan secara konkret semua unsur dan perihal tentang kehidupan berbangsa dan bernegara. Maka tidak berlebihan jika Abu Hamid al-Gazali mengatakan: "tegaknya agama sangat tergantung pada tegaknya urusan dunia dan sistemnya". ${ }^{15}$

Lain halnya dalam sejarah Eropa, awal hubungan antara agama dan negara terjadi pada abad pertengahan yang ditandai oleh dominasi agama Kristen dalam kehidupan bernegara. Pada masa itu muncul negara teokrasi mutlak dari Agustinus. Negara di bumi dalam pandangan Agustinus seperti layaknya negara Iblis yang hanya akan memberikan kesengsaraan bagi manusia. Untuk itu Agustinus kemudian mendambakan negara ketuhanan yang membawa kedamaian dan ketenteraman.

\footnotetext{
${ }^{14}$ Muhammad Yusuf Musa, Al-Islam ...hlm. 40.

${ }^{15}$ Abu Hamid al-Gazali, Al-Wasit fi al-Mazhab, Jld 7, Dar Assalam, Kairo, hlm.7.
} 
Dominasi gereja sebagai institusi agama ternyata membelenggu kebebasan berpikir yang menyebabkan Eropa masuk dalam abad kegelapan (the dark age). Gugatan-gugatan kepada peran gereja tak terelakkan yang akhirnya mampu mengakhiri peran dominan tersebut. Masa kemenangan ini dinamakan sebagai pencerahan (renaisans). Pada abad pencerahan, peran agama dan negara mengalami sebuah perubahan yang cukup signifikan. Ketika itu, para ahli pikir menemukan konsep perlunya pemisahan antara agama dan negara, dan konsep ini merupakan awal munculnya teori negara sekuler. ${ }^{16}$

Sementara itu, dalam pandangan Islam, agama merupakan satu-satunya frame dimana semua manusia dapat hidup di bawah naungannya karena agama dapat memenuhi penyelesaian semua kebutuhan manusia dengan memberikan kehidupan yang lebih tenang dan aman dengan dasar kerjasama serta membangun kesepahaman antara satu dengan lain dalam bingkai kasih sayang dan saling hormat-menghormati. Agama dapat menyatukan antara tuntutan pribadi setiap orang dengan kepentingan orang banyak; dan inilah sebenarnya konsep yang ditawarkan oleh agama yang dapat menyelesaikan semua masalah yang terjadi di tengah-tengah masyarakat. ${ }^{17}$

Manusia tidak akan dibiarkan oleh agama untuk menyelesaikan masalah mereka sendiri seperti halnya yang dikatakan oleh para kaum materialis. Begitu juga mereka tidak akan diselesaikan masalahnya oleh ilmu pengetahuan semata seperti yang dikatakan oleh para ilmuan yang memandang ilmu sebagai sesuatu yang selalu berkembang. Sehebat apapun yang telah dicapai oleh para ilmuan dan kelompok materialistis tidak akan pernah dapat menyelesaikan masalah mereka bila agama tidak dilibatkan di dalamnya. Buktinya dengan majunya ilmu pengetahuan, manusia tidak henti-hentinya saling memusuhi antara satu dengan yang lain, bahkan saling membunuh dan menghancurkan hanya karena persoalan materi, kekuasaan dan berbagai macam kepentingan lainnya.

${ }^{16}$ Ayi Sofyan, 2012, Etika Politik Islam, Pustaka Setia, Bandung, hlm.76.

${ }^{17}$ Sebagian pakar mengatakan bahwa kitab suci agama Yahudi dan Nasrani terlepas dan sunyi dari syariat dan aturan yang cocok dan tepat untuk mambangun umat dan negara. Lihat Muhammad Yusuf Musa, al-Islam...hlm. 41. 
Di dalam Islam, kepentingan pribadi dapat disatukan dengan kepentingan orang banyak. Sebab dua kepentingan tersebut saling terkait karena dengan menjaga kepentingan orang banyak berarti juga sudah menjaga kepentingan perorangan. Dengan demikian semua elemen masyarakat akan mengerti dan memahami bahwa ia tidak boleh egois, karena bagaimana pun juga ia tetap membutuhkan kehadiran orang lain yang kemudian menciptakan suasana kehidupan yang penuh dengan kedamaian dan kesepahaman. Melibatkan agama dalam setiap dimensi kehidupan akan senantiasa membentuk pribadi yang saleh secara individu dan saleh secara sosial karena memiliki kepedulian terhadap sesama. Suasana yang menyejukkan itu banyak ditegaskan oleh Allah dalam alQur'an:

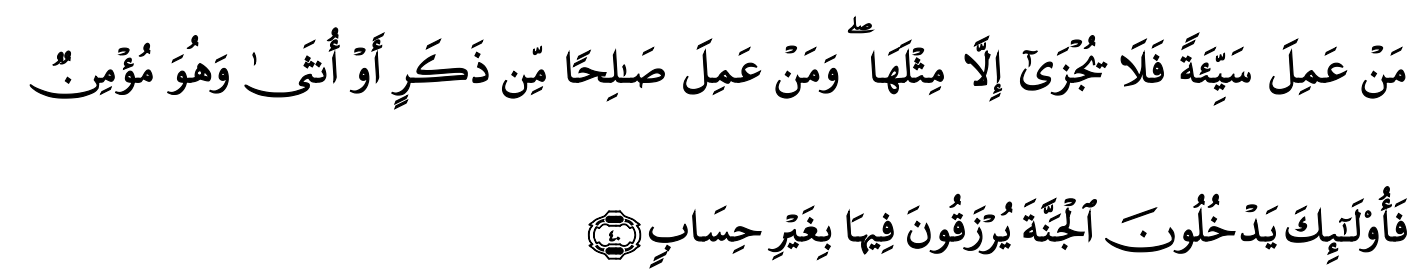

"Barangsiapa mengerjakan perbuatan jahat, maka dia tidak akan dibalasi melainkan sebanding dengan kejahatan itu. Dan barangsiapa mengerjakan amal yang saleh baik laki-laki maupun perempuan sedang ia dalam keadaan beriman, maka mereka akan masuk surga, mereka diberi rezeki di dalamnya tanpa hisab”. (QS.Gafir: 40).

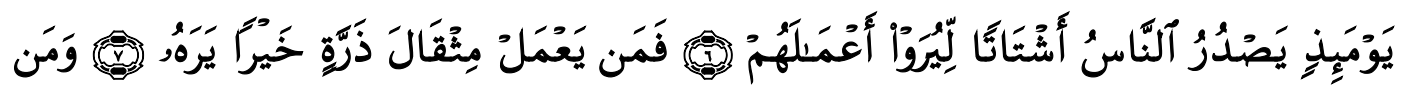

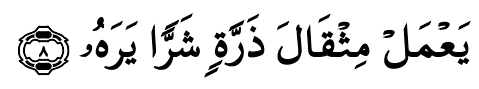

"Pada hari itu manusia ke luar dari kuburnya dalam keadaan bermacammacam, supaya diperlihatkan kepada mereka (balasan) pekerjaan mereka. Barangsiapa yang mengerjakan kebaikan seberat dzarrahpun, niscaya dia akan melihat (balasan)nya. Dan barangsiapa yang mengerjakan kejahatan sebesar dzarrahpun, niscaya dia akan melihat (balasan) nya pula". (QS. Azzalzalah: 6-8). 


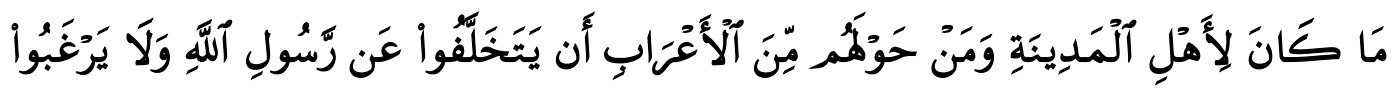

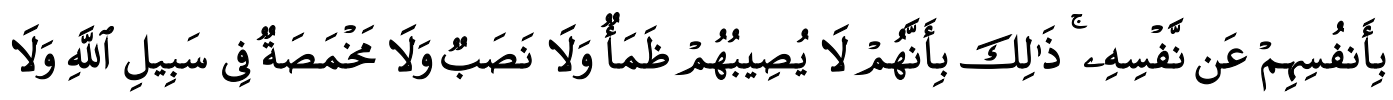

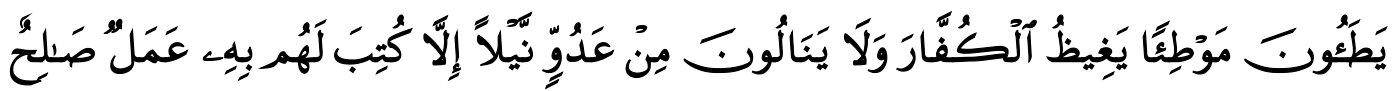

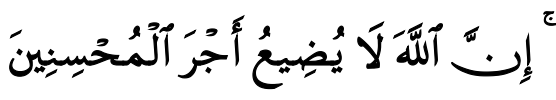

"Tidaklah sepatutnya bagi penduduk Madinah dan orang-orang Arab Badwi yang berdiam di sekitar mereka, tidak turut menyertai Rasulullah (berperang) dan tidak patut (pula) bagi mereka lebih mencintai diri mereka daripada mencintai diri Rasul. Yang demikian itu ialah karena mereka tidak ditimpa kehausan, kepayahan dan kelaparan pada jalan Allah, dan tidak (pula) menginjak suatu tempat yang membangkitkan amarah orangorang kafir, dan tidak menimpakan sesuatu bencana kepada musuh, melainkan dituliskanlah bagi mereka dengan yang demikian itu suatu amal saleh. Sesungguhnya Allah tidak menyia-nyiakan pahala orang-orang yang berbuat baik".(QS. Attaubah: 120).

Kalau dicermati ayat-ayat tersebut di atas maka nampak jelas menyatukan antara akidah, hukum dan kehidupan dalam suatu komunitas masyarakat yang selalu menjalin kerjasama baik dalam keadaan perang maupun dalam keadaan damai di samping menjadikan kepentingan umum sebagai bagian dari kepentingan perorangan begitu juga sebaliknya. Oleh sebab itu, agama merupakan kebutuhan secara fitrah bagi manusia, dan fitrah itu sebenarnya dasar utama yang selalu mendorong manusia menampakkan gejolak jiwanya yang terkadang menimbulkan masalah sosial. Tetapi dengan cenderungnya manusia kepada nilai-nilai transenden agama akan dapat menimalisir dan bahkan menyelesaikan semua masalah yang muncul di tengah-tengah mereka. ${ }^{18}$

\footnotetext{
${ }^{18}$ Ahmad al-Hushariy, Addaulatu Wasiyasatu al-Hukmi fi al-Fikhi al-Islami, Maktabah alKulliyat al-Azhariyah, Kairo, hlm.15.
} 
Para sarjana Muslim telah menjelaskan tentang pentingnya kehadiran sebuah kekuasaan di tengah-tengah masyarakat. Alasannya sangat sederhana yakni baik buruknya kehidupan suatu komunitas masyarakat sangat ditentukan oleh adanya lembaga yang mengatur mereka. Hal itu disebabkan karena manusia adalah mahluk sosial sehingga komunikasi serta interaksi antara satu dengan yang lain tidak dapat dihindari. Komunikasi dan interaksi di antara mereka sudah pasti terjadi sehingga akan bermunculan berbagai macam masalah akibat berbedanya kepentingan. Olehnya itu, kehadiran sebuah kekuasaan sangat dibutuhkan sebagai penengah dan penyeimbang yang keputusannya dapat diterima oleh semua pihak.

Abul Hasan al-Mawardi $(364-450 \mathrm{H})$ menjelaskan secara gamlang bahwa manusia selalu membutuhkan kehadiran orang lain untuk membantunya memenuhi keperluan hidupnya. Kesalehan pribadi tidak akan tercipta sebelum terciptanya kesalehan sosial, begitu juga sebaliknya. Olehnya itu kebajikan dunia sangat ditentukan oleh dua hal, pertama, segala sesuatu yang dapat mengaturnya dengan baik; dan yang kedua adalah segala sesuatu yang dapat membuat keadaan setiap individu menjadi baik. Kedua faktor tersebut oleh al-Mawardi tidak boleh dipisahkan karena jika hal itu terjadi maka kehidupan akan mengalami kepincangan. Seorang yang kondisi batinnya baik tetapi kehidupan dunianya bermasalah tidak menutup kemungkinan batinnya akan terganggu. Sebaliknya seorang yang kondisi batinnya bermasalah walaupun kondisi dunianya baik pasti tidak akan merasa tenang. Hal itu terjadi karena manusia hakekatnya adalah dunianya sendiri sehingga ia selalu beranggapan bahwa kebajikan hanya ada bila kehidupan dunia menjadi baik baginya. Begitu juga sebaliknya, ia selalu beranggapan bahwa keburukan hanya ada jika kehidupan dunia tidak berpihak kepadanya. $^{19}$

Islam tidak memisahkan antara urusan akhirat dengan urusan dunia; dan juga tidak membedakan antara maslahat pribadi dengan maslahat orang banyak, tetapi justru berusaha menciptakan kebahagian dunia akhirat baik secara perorangan maupun kelompok. Islam adalah agama yang membawa hukum dan

19 Abul Hasan al-Mawardi, Adabu Addun-ya wa Addin, Tab'ah al-Kahirah, Kairo , hlm.134. 
aturan yang dapat membahagiakan manusia dalam kehidupan dunia seperti hukum muamalah, hukum pidana, hukum bisnis, hukum perdata, hukum internasional, dan sistem hukum yang meliputi masalah kebebasan, persamaan hak, musyawarah, keadilan dan kepedulian sosial.

Selain itu, Islam juga datang dengan hukum-hukum yang dapat membahagiakan manusia dalam kehidupan akhirat seperti hukum ibadah termasuk bersuci, shalat, puasa, zakat, haji, dan kemuliaan amalan-amalan dan semua yang berkaitan dengan hubungan manusia dengan penciptanya. ${ }^{20}$ Karenanya, Islam mengajarkan tentang pentingnya menjaga keseimbangan kehidupan dunia dengan kehidupan akhirat. Dalam hidup ini, seseorang tidak boleh mengabaikan kehidupan dunianya karena akhiratnya, begitu juga sebaliknya tidak boleh mengabaikan akhirat karena dunia semata. Allah berfirman:

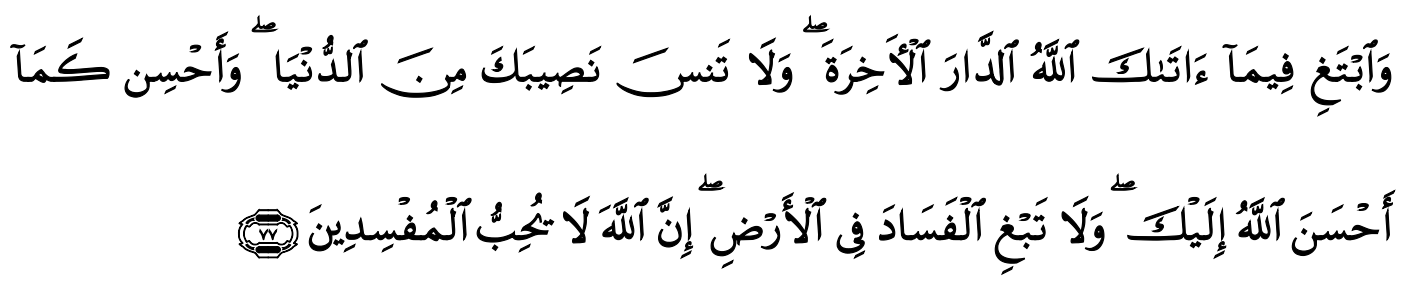

"Dan carilah pada apa yang telah dianugerahkan Allah kepadamu (kebahagiaan) negeri akhirat, dan janganlah kamu melupakan bahagianmu dari (kenikmatan) duniawi dan berbuat baiklah (kepada orang lain) sebagaimana Allah telah berbuat baik, kepadamu, dan janganlah kamu berbuat kerusakan di (muka) bumi. Sesungguhnya Allah tidak menyukai orang-orang yang berbuat kerusakan”. (QS. al-Qasas: 77).
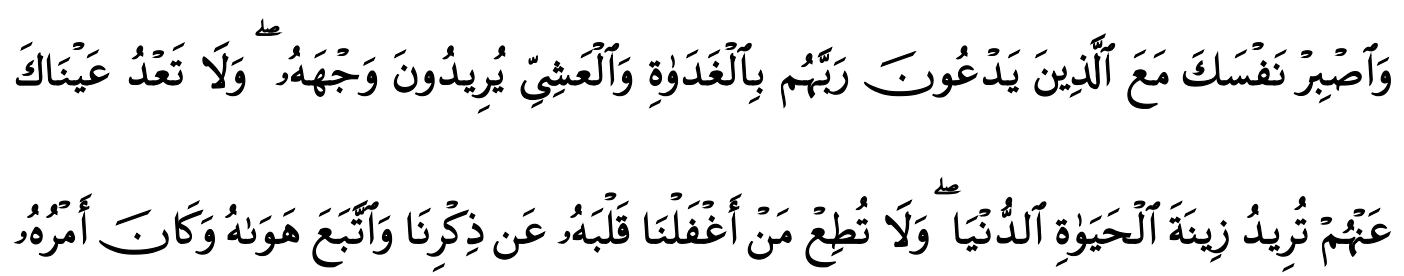

\footnotetext{
${ }^{20}$ Ismail Badawi, Nazariyah Addaulah...hlm.14-15.
} 
"Dan bersabarlah kamu bersama-sama dengan orang-orang yang menyeru Tuhannya di pagi dan senja hari dengan mengharap keridhaan-Nya; dan janganlah kedua matamu berpaling dari mereka (karena) mengharapkan perhiasan dunia ini; dan janganlah kamu mengikuti orang yang hatinya telah Kami lalaikan dari mengingati Kami, serta menuruti hawa nafsunya dan adalah keadaannya itu melewati batas". (QS.al-Kahfi: 28).

Disebutkan dalam hadis riwayat Bukhari dan Muslim dari Anas bin Malik bahwa Aisyah isteri Nabi pernah didatangi beberapa sahabat. Lalu di antara sahabat itu ada yang mengatakan ia tidak akan menikah, yang satu lagi mengatakan akan shalat dan tidak tidur, yang satunya lagi mengatakan akan berpuasa dan tidak makan. Ketika Nabi mengetahui hal tersebut beliau pun mengatakan: "sesungguhnya aku shalat dan tidur, puasa dan makan, dan menikahi perempuan, barang siapa yang enggan terhadap sunnahku maka ia bukan bagian dariku". ${ }^{21}$

Ayat-ayat al-Qur'an sendiri banyak yang mengisyaratkan adanya pemikiran dan petunjuk kepada Nabi tentang pentingnya mendirikan negara demi membangun kehidupan dunia yang bermartabat dengan berlandaskan nilai-nilai agama. Ayat yang dimaksud antara lain firman Allah surat Annisa' ayat 59 dan 83, dan surat Ali Imran ayat 159. Secara implisit kedua ayat itu menjelaskan adanya penekanan terbentuknya suatu negara yang memiliki pemimpin yang melek dan mengerti kebutuhan masyarakat serta pentingnya masyarakat itu tunduk pada pemimpinnya. Salah satu hak pemimpin adalah mendapatkan dukungan dari masyarakat, sedangkan kewajiban masyarakat ialah bekerjasama dengan pemimpinnya karena kerjasama itu pembumiannya dituntut di dalam agama. Allah berfirman:

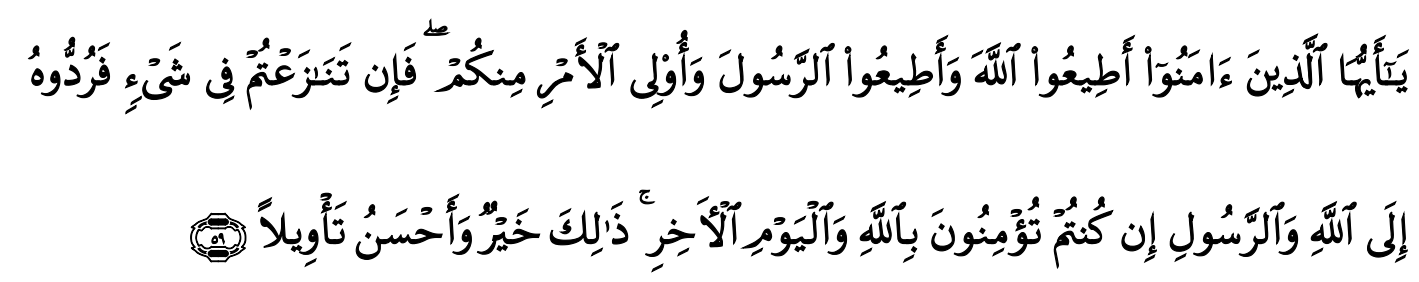

\footnotetext{
${ }^{21}$ Hadis riwayat Bukhari dan Muslim.
} 
"Hai orang-orang yang beriman, taatilah Allah dan taatilah Rasul (Nya), dan ulil amri di antara kamu. Kemudian jika kamu berlainan pendapat tentang sesuatu, maka kembalikanlah ia kepada Allah (Al Quran) dan Rasul (sunnahnya), jika kamu benar-benar beriman kepada Allah dan hari kemudian. Yang demikian itu lebih utama (bagimu) dan lebih baik akibatnya”. (QS.Annisa': 59).

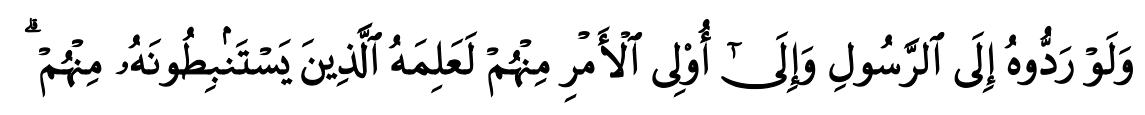

"Dan kalau mereka menyerahkannya kepada Rasul dan Ulil Amri di antara mereka, tentulah orang-orang yang ingin mengetahui kebenarannya (akan dapat) mengetahuinya dari mereka (Rasul dan Ulil Amri).”.(QS.Annisa': 83).

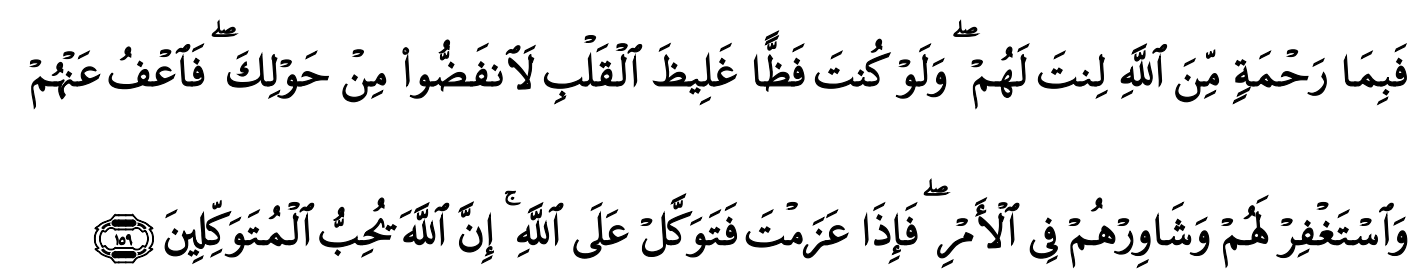

"Maka disebabkan rahmat dari Allah-lah kamu berlaku lemah lembut terhadap mereka. Sekiranya kamu bersikap keras lagi berhati kasar, tentulah mereka menjauhkan diri dari sekelilingmu. Karena itu maafkanlah mereka, mohonkanlah ampun bagi mereka, dan bermusyawaratlah dengan mereka dalam urusan itu. Kemudian apabila kamu telah membulatkan tekad, maka bertawakkallah kepada Allah. Sesungguhnya Allah menyukai orang-orang yang bertawakkal kepada-Nya”. (QS.Ali Imran: 159).

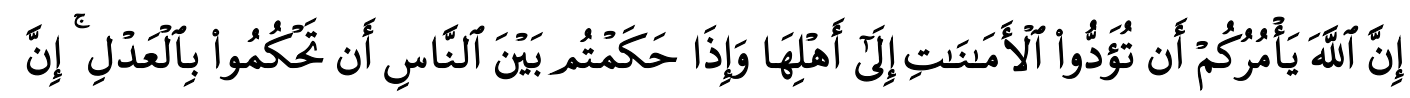

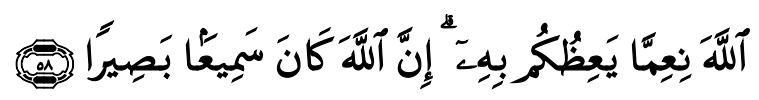

"Sesungguhnya Allah menyuruh kamu menyampaikan amanat kepada yang berhak menerimanya, dan (menyuruh kamu) apabila menetapkan hukum di antara manusia supaya kamu menetapkan dengan adil. 
Sesungguhnya Allah memberi pengajaran yang sebaik-baiknya kepadamu. Sesungguhnya Allah adalah Maha Mendengar lagi Maha Melihat”. (QS. Annisa': 58).
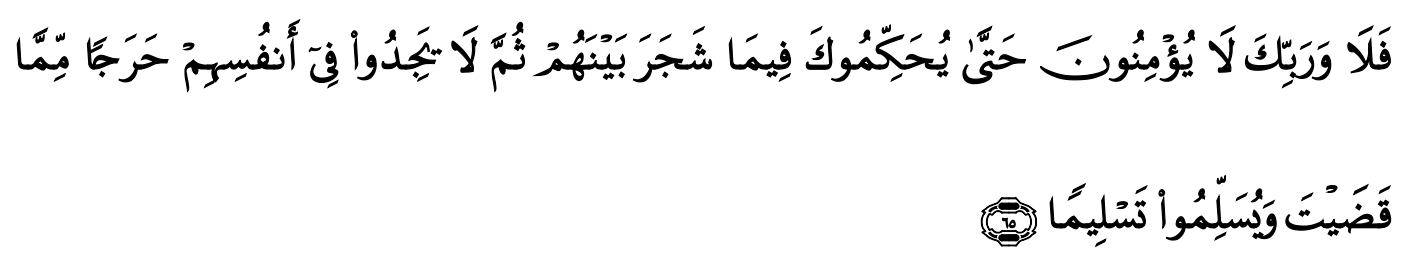

"Maka demi Tuhanmu, mereka (pada hakekatnya) tidak beriman hingga mereka menjadikan kamu hakim terhadap perkara yang mereka perselisihkan, kemudian mereka tidak merasa dalam hati mereka sesuatu keberatan terhadap putusan yang kamu berikan, dan mereka menerima dengan sepenuhnya". (QS. Annisa': 65).

Allah SWT dalam ayat tersebut di atas mengajarkan kepada Nabi dan para pemimpin yang datang setelahnya tentang tata kelola pemerintahan. Seorang pemimpin harus betul-betul paham masalah yang sedang dihadapi oleh masyarakatnya sehingga tidak mengeluarkan intruksi atau kebijakan kecuali jelas sisi positif dan negatifnya kebijakan itu. Bahkan kalau perlu kebijakan-kebijakan itu dikeluarkan setelah melalui musyawarah dan diyakini sebagai pro-rakyat demi kemaslahatan. Kalau itu dilakukan sesuai dengan petunjuk agama maka kemudian hasilnya diserahkan sepenuhnya kepada Allah. Nilai-nilai tersebut telah dibumikan oleh Nabi dan para sahabatnya karena merupakan bagian yang tidak terpisahkan dari tugas-tugas negara. ${ }^{22}$

Dalam diskursus pemikiran Islam, tugas-tugas negara antara lain: ${ }^{23}$

1. Memelihara agama serta menjaga kehidupan beragama dari segala hal yang dapat mencederainya.

2. Berkewajiban memberikan kebebasan kepada seluruh rakyatnya termasuk orang Islam untuk menyebarkan dakwah dengan berbagai cara yang rasional dan tidak memaksa.

3. Menegakkan hukum.

\footnotetext{
${ }^{22}$ Ahmad al-Hushariy, Addaulatu Wasiyasatu al-Hukmi ...hlm. 17.

${ }^{23}$ Ahmad al-Hushariy, Addaulatu Wasiyasatu al-Hukmi... hlm. 318.
} 
4. Menjaga stabilitas dan keamanan negara.

5. Membentuk masyarakat yang rukun, damai, dan saling tolongmenolong dalam kebaikan dalam suatu bingkai yang disebut al-amru bil ma'rufi wannahyu anilmunkari.

Semua nilai-nilai itu berdasar pada firman Allah SWT.

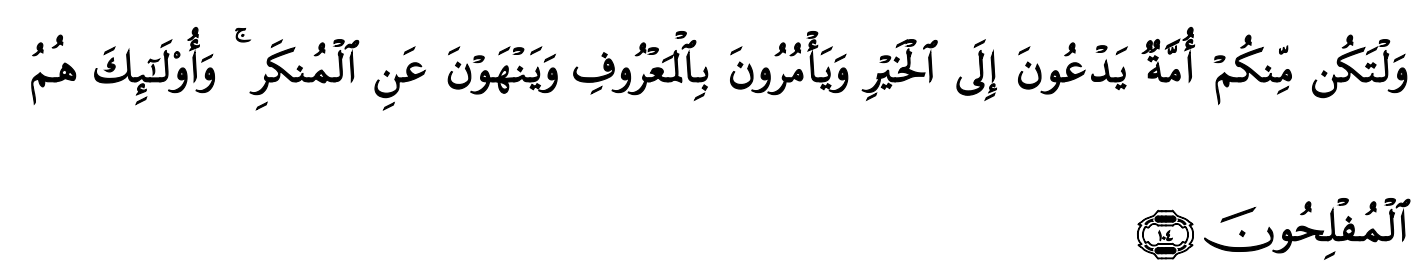

"Dan hendaklah ada di antara kamu segolongan umat yang menyeru kepada kebajikan, menyuruh kepada yang ma'ruf dan mencegah dari yang munkar; merekalah orang-orang yang beruntung" (QS. Ali Imran: 3/104).

Ayat di atas menunjukkan bahwa membentuk lembaga pemerintahan yang memiliki otoritas dan kekuasaan atas nama rakyat untuk menjalankan tugas-tugas pokoknya sebagai negara adalah wajib hukumnya. Sedangkan tugas pokok yang dimaksud adalah mengajak kepada kebajikan, menegakkan kebenaran dan mencegah kemungkaran. ${ }^{24}$ Dengan tiga pointer tadi maka lahirlah apa yang disebut dengan komunitas kecil yang kemudian berobah menjadi komunitas besar yakni masyarakat di bawah satu payung hukum dalam suatu negara. Kemudian dapat dipastikan bahwa agama tidak membedakan antara urusan dunia dengan urusan akhirat. Begitu pula agama tidak membedakan antara kemaslahatan perorangan dengan kemaslahatan orang banyak. Justru Islam sebagai agama berusaha untuk membahagiakan semuanya baik di dunia maupun di akhirat.

Syariat Islam adalah syariat yang bersifat menyeluruh dan paripurna, di dalamnya terdapat berbagai macam aturan dan hukum yang dengannya manusia dapat meraih kehidupan yang bahagia di dunia dan pencapaian kebahagiaan akhirat. Itulah sebabnya mengapa Islam mewasiatkan kepada manusia agar

\footnotetext{
${ }^{24}$ Ahmad al-Hushariy, Addaulatu... hlm .321.
} 
senantiasa hidup dengan penuh keseimbangan antara tuntutan dunia dengan tuntutan akhirat. Siapa pun tidak boleh mengabaikan akhiratnya hanya karena dunia semata yang dipikirkan. Begitu pula sebaliknya, siapa pun tidak boleh mengabaikan urusan dunianya disebabkan karena hanya fokus pada akhirat saja.

Dalam berbagai kesempatan Nabi menegaskan tentang perlunya mendirikan sebuah negara. Penegasan tersebut dapat diidentifikasi dari beberapa hadis beliau antara lain:

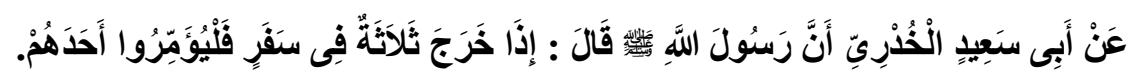

"Dari Abu Said al-Khudri bahwasanya Nabi bersabda: jika ada tiga orang melakukan perjalanan maka sebaiknya ada salah satu dari mereka yang memimpin". 25

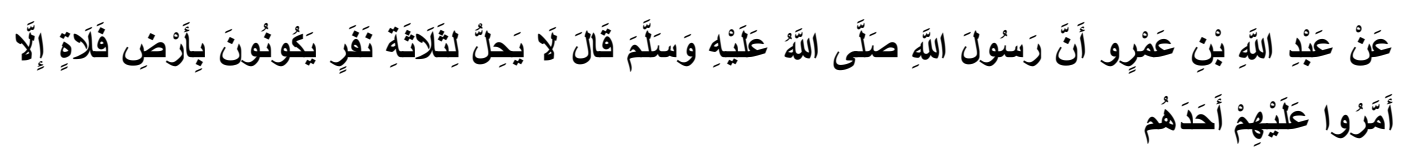

"Dari Abdullah bin Amru, Nabi bersabda: tidah dihalalkan/dibolehkan bagi tiga orang yang sedang berada di padang yang luas kecuali salah satu dari mereka ada yang memimpin". 26

Dari kedua hadis tersebut Nabi nampaknya tidak mengizinkan sekelompok orang melakukan perjalanan kecuali satu diantara mereka ada yang memimpin. Jika kelompok kecil saja harus ada yang pimpin, maka dapat dipastikan beliau tidak akan membiarkan ribuan bahkan jutaan orang tanpa pemimpin. Kehadiran seorang pemimpin dalam sebuah komunitas masyarakat bertujuan untuk menegakkan hukum termasuk juga menyiapkan bala tentara untuk menjaga keamanan dan keselamatan semua orang dari berbagai macam ancaman baik yang datang dari dalam maupun dari luar; dan itulah yang disebut negara.

${ }^{25}$ Sulaiman bin Ahmad Attabrani, 1415 H, al-Mu'jam al-Aushat, Dar al-Haramain,Kairo, Jld.8.Hal. .99.

${ }^{26}$ Untuk lebih lengkapnya matan hadis tersebut lihat Alauddin Ali bin Hisamuddin alHindiy, Kanzu al-Ummal, (Bairut: Muassasah al-Risalah, 1981), Jld.16.hlm. 331.Lihat juga Ahmad bin Hanbal, Musnad Ahmad bin Hanbal, (Kairo: Muassasah Qurtubah, t.th.), Jld.2.hlm .176 . 
Kalau saja ada yang meragukan terbentuknya negara dan pemerintahan oleh Nabi ketika di Madinah maka pertanyaannya adalah apa sebenarnya yang disebut negara serta bagaimana tata kelola sebuah pemerintahan? Bukankah penegakan hukum, banyaknya perjanjian serta penyelesaian konflik oleh Nabi kala itu termasuk tanggung jawab pemerintah dalam suatu negara? Tentu jawabannya adalah tanggung jawab pemerintah selaku pelaksana undang-undang. Karenanya dalam kurun waktu yang tidak lama, Nabi telah menyatakan berdirinya negara Madinah sebagai implementasi dari unsur pokok dalam mendirikan negara sebagaimana dikenal dalam hukum tata negara konvensiaonal yakni harus ada masyarakat, ada tatanan hukum yang mengatur, ada wilayah, dan ada pemimpin yang menjalankan pemerintahan. Semua unsur yang disebutkan itu telah terpenuhi dan tertera dalam pidato Nabi pada saat memproklamerkan berdirinya negara Madinah. Berikut cuplikan deklarasi Nabi yang lebih dikenal dengan mitsaq madinah atau piagam Madinah.

Piagam Madinah oleh para sarjana muslim dianggap sebagai konstitusi pertama yang menekankan pentingnya saling membantu, bekerjasama dan tidak saling memusuhi. Selain itu, perjanjian tersebut juga sebagai bukti bahwa Islam adalah agama yang toleran dan tidak membedakan antara seorang muslim dengan non muslim. ${ }^{27}$ Muhammad Hamidullah menuliskan beberapa pernyataannya terkait dengan piagam Madinah. Menurutnya, Undang Undang Dasar Negara tertulis pertama yang pernah dikemukakan oleh penguasa dalam sejarah ummat manusia ternyata diumumkan oleh Nabi Muhammad, yakni pada tahun pertama Hijriah (622 M), dan sekarang Undang Undang Dasar tersebut telah sampai di tangan kita. Ia juga menyatakan bahwa fakta pertahanan ini sangat diperlukan untuk membentuk negara di Madinah yang berasaskan persekutuan dengan otonomi yang sangat luas bagi setiap unitnya. ${ }^{28}$

\footnotetext{
${ }^{27}$ Muhammad Bahauddin Salim, al-Islam, Addin, wa Addaulah... hlm. 43.

${ }^{28}$ Muhammad Bahauddin Salim, al-Islam, Addin, wa Addaulah... hlm. 43.
} 
Hasan Ibrahim Hasan, seorang pemikir Islam Mesir juga menyatakan bahwa Piagam Madinah secara resmi menandakan berdirinya suatu negara, yang isinya dapat disimpulkan menjadi empat pokok, yaitu: ${ }^{29}$

1. Mempersatukan segenap kaum muslimin dari berbagai suku menjadi satu ikatan.

2. Menghidupkan semangat gotong royong, hidup berdampingan, saling menjamin di antara sesama warga.

3. Menetapkan bahwa setiap warga masyarakat mempunyai kewajiban memanggul senjata, mempertahankan keamanan dan melindungi Madinah dari serbuan luar.

4. Menjamin persamaan dan kebebasan bagi kaum Yahudi dan pemelukpemeluk agama lain dalam mengurus kepentingan mereka.

Adanya penyatuan antara nilai-nilai agama dengan sistem bernegara bertujuan untuk menegakkan keadilan di samping menjelaskan tentang batas-batas segala sesuatunya yang harus diindahkan bilamana terjadi perjanjian atau suatu kesepakatan baik yang bersifat internal maupun eksternal. Nilai-nilai itulah yang telah dibumikan oleh Nabi sebagai penyampai risalah keadilan serta keselamatan yang diterima dari Allah SWT.

Hal yang menarik dari piagam tersebut bila dilihat dari perspektif kekinian ialah adanya kaidah-kaidah yang bersifat umum yang dapat mengakomodir berbagai problema kekinian dalam semua lini dan aspek perundang-undangan, baik berkaitan dengan masalah dalam negeri maupaun luar negeri. Piagam itu memuat hak-hak golongan mayoritas dan hak-hak mereka dalam menjalankan agamanya. Di dalam konstitusi ini terdapat prinsip-prinsip kehidupan sosial yang sangat relevan dengan komunitas muslim pada khususnya dan masyarakat negara pada umumnya. Umat Islam tunduk pada atauran konstitusi dan ajaran Islam. Mereka adalah satu komunitas yang berjalan di atas tuntunan Islam. Mereka berkewajiban untuk bersikap egalitarian dan memberikan perlindungan terhadap kelompok minoritas yang tidak berkhianat dan kelompok yang beraliansi dengan orang-orang Islam. Di dalam piagam itu, terdapat ketentuan yang menyatakan:

${ }^{29}$ Muhammad Bahauddin Salim, al-Islam, Addin, wa Addaulah... h.43. 
“Orang Yahudi yang menyatakan beraliansi ke dalam negara Islam, ia berhak mendapat perlindungan dan perlakuan yang sama. Dia tidak boleh diperlakukan sewenang-wenang dan tidak boleh pula memberikan bantuan kepada musuhnya". 30

Di dalam piagam ini terdapat ketentuan yang secara tegas menyatakan bahwa kedaulatan negara atas semua kelompok masyarakat yang menjalin hubungan bilateral dengan masyarakat muslim. Demikian juga dalam hubungan antar kelompok masyarakat dengan kelompok yang lain. Bahkan, jika ditelusuri lebih dalam lagi, piagam itu memuat juga ketentuan tentang aliansi militer sebagaimana negara serikat- dalam memerangi musuh negara. Menurut ketentuan piagam itu, orang-orang Yahudi wajib menanggung pendanaan bersama-sama dengan orang Islam selama dalam pertempuran. Orang-orang Yahudi berkewajiban membiayai orang-orang Islam. Kedua belah pihak sama-sama berkewajiban membela Yastrib dari serangan musuh. ${ }^{31}$

Kehadiran piagam Madinah dalam pentas sejarah telah mendapat berbagai komentar dari berbagai kalangan tidak hanya dari para sarjana muslim tetapi juga datang dari para sarjana barat, antara lain:

1. A. Guillaume penulis "The Life of Muhammad" menyatakan bahwa piagam yang telah dibuat Muhammad itu adalah suatu dokumen yang menekankan hidup berdampingan antara orang-orang Muhajirin di satu pihak dan orang-orang Yahudi di pihak lain. Masing-masing saling menghargai agama mereka, saling melindungi hak milik mereka, dan masing-masing mempunyai kewajiban yang sama dalam mempertahankan Madinah. ${ }^{32}$

2. Robert N.Bella menuliskan dalam bukunya "Beyond Belief" bahwa Muhammad sebenarnya telah membuat lompatan yang amat jauh ke depan. Dimulai dengan "proyek" Madinah yang dilandasi pada permulaan berdirinya "Konstitusi Madinah" ini, menurut Bella,

\footnotetext{
${ }^{30}$ A. Gaffar Aziz, 2000, Berpolitik untuk Agama, Pustaka Pelajar ,Yogyakarta, hlm.140.

${ }^{31}$ A. Gaffar Aziz, Berpolitik untuk Agama... hlm. 141.

${ }^{32}$ Mohammad Arifudin, (http://ibnunahl09.blogspot.co.id/2012/06/. diakses 26 November 2016.
} 
Muhammad telah melahirkan sesuatu yang untuk zaman dan tempatnya adalah sangat modern.

3. Montgomery Watt menyatakan bahwa piagam Madinah tidak lain adalah suatu konstitusi yang menggambarkan bahwa warga Madinah saat itu bisa dianggap telah membentuk satu kesatuan politik dan satu persekutuan yang diikat oleh perjanjian yang luhur di antara para warganya. $^{33}$

4. Tor Andrae bahwa: "Perundang-undangan jamaah (ummah) Madinah adalah naskah konstitusi yang pertama yang sedikit demi sedikit dapat menjadikan Islam sebagai negara dunia dan agama dunia...Barangsiapa yang tindakannya berlawanan dengan otoritas keagamaan, maka ia tidak akan mendapat perlindungan dari keluarganya yang terdekat sekalipun. Islam tidak hanya agama, tetapi juga merupakan persaudaraan. Semata-mata orang beriman itu saling bersaudara.., demikian pernyataan al-Qur'an, al-Hujurat, 49:10". ${ }^{34}$

Piagam Madinah dianggap sebagai suatu kebijaksanaan politik yang luar biasa dari Nabi dalam mengantisipasi terjadinya berbagai kemungkinan yang tidak diinginkan dalam suatu masyarakat yang heterogen, beraneka ragam warna kulit, ras, dan bahkan agama. Secara implisit dapat disimpulkan bahwa piagam Madinah mencakup seluruh aspek dan tatanan kehidupan manusia dalam bermasyarakat, berbangsa dan bernegara karena piagam Madinah telah menjelaskan tentang pembentukan ummat, hak asasi manusia, persatuan negara, persatuan segenap warga negara, golongan minoritas, tugas warga negara, melindungi negara, pimpinan negara, dan politik perdamaian.

Memang Nabi tidak pernah merumuskan secara konstan mengenai bentuk negara/pemerintahan yang harus diikuti oleh para pemimpin yang datang kemudian. Tetapi bukan berarti bahwa ia sama sekali tidak mengusung mekanisme politik yang dijadikan sebagai standar. Justru beliau telah berhasil menggagas sekaligus membumikan banyak konsep dan teori tentang kehidupan

\footnotetext{
${ }^{33}$ Mohammad Arifudin, (http://ibnunahl09.blogspot.co.id/2012/06/. diakses 26 November 2016.

${ }^{34}$ Tor Andrae,1960, Muhammad, The Man and His Faith, New York, 1960, hlm.136.
} 
berbangsa dan bernegara. Bukankah Nabi telah berbicara banyak soal keadilan, kesejahteraan, musyawarah, penerapan hukum pidana, persamaan hak dan kewajiban, toleransi, pengangkatan aparat negara, para pemimpin pasukan, dan bahkan masalah-masalah sosial politik yang berkaitan dengan hubungan luar negeri misalnya pengutusan delegasi ke beberapa negeri tetangga untuk menyampaikan risalah Islam atau bertujuan menjalin hubungan kerjasama dalam berbagai bidang. ${ }^{35}$

Ibnu Hisyam dan Abu Ja'far Attabari mengisahkan beberapa sahabat yang diutus oleh Nabi pada tahun ke $6 \mathrm{H}$. sebagai duta ke beberapa wilayah kerajaan yang ada pada saat itu. Misalnya Hatib bin Abi Balta'ah diutus oleh Nabi ke Mukaukes raja Iskandariah yang dipertuan agung di Mesir. Dihyah bin Khalifah al-Qalbiy al-Khazrajiy yang diutus ke Herakel kaisar Romawi. Salit bin Amru bin Abdu Syams diutus ke Huzah bin Ali al-Hanafi penguasa Yamamah. Al-Ala' bin al-Hadramiy diutus ke Munzir bin Sawi saudara Bani Abdil Qais penguasa Bahrain. Amru bin Ash diutus ke Ubbad bin Jalandiy al-Azdiy penguasa Omman. Abdullah bin Huzafah Assahmiy diutus ke Kisra raja Persia. Dan yang terakhir adalah Amru bin Umayyah al-Gumariy yang diutus ke raja Najasyi. ${ }^{36}$

Maka dari itu dapat dilihat pemetaan wilayah kekuasaan Islam dari masa ke masa. Pada masa Nabi, wilayah kekuasaan Islam meliputi jazirah Arab. Sedangkan pada masa pemerintahan Abu Bakar, wilayah Islam meliputi Makkah, Madinah, Thaif, San'a', Hadramaut, Khulan, Zabid, Rama', Najran, Jars, dan Bahrain. Lalu pada masa pemerintahan Umar bin Khattab, ia membagi wilayah kekuasaan Islam menjadi beberapa wilayah besar yakni, wilayah Ahwaz dan Bahrain, wilayah Zijistan dan Makran, wilayah Tibirstan, dan wilayah Khurasan. Selain itu Umar bin Khattab membagi wilayah Irak ke dalam dua wilayah besar yakni, Kufah dan Basrah. Sedangkan wilayah Syam dibagi ke dalam beberapa wilayah yakni, Hims, Damaskus, dan Palestina berdiri sendiri. Adapun wilayah

\footnotetext{
${ }^{35}$ Ahmad al-Hushariy, Addaulatu Wasiyasatu al-Hukmi... hlm.29, 30.

${ }^{36}$ Ibnu Hisyam, Assirah Annabawiyah, (Kairo: Dar Attahrir), Jld.4.hlm. 216. Abu Ja'far Attabari, Tarikh Attabari, (Kairo: Dar al-Ma'arif), Jld.2. hlm..644.
} 
Afrika, Umar membaginya ke dalam tiga bagian yakni, Mesir Ulya, Mesir Sufla' dan wilayah Mesir bagian barat serta padang pasir Libya. ${ }^{37}$

Pada masa pemerintahan Dinasti Umawiyah, wilayah kekuasaan Islam dibagi ke dalam lima bagian. Pertama, wilayah Hijaz, Yaman, dan daerah Arab bagian tengah. Kedua, wilayah Mesir ulya dan Mesir sufla'. Ketiga, wilayah Irak dan Masyrik. Keempat, wilayah semenanjung Arab termasuk Armenia, Azarbaijan, dan beberapa wilayah Asia kecil. Kelima, wilayah Afrika yang meliputi Magrib tengah, Magrib jauh, dan Andalusia. ${ }^{38}$

Sedangkan pada masa pemerintahan Dinasti Abbasiyah, pada awalnya wilayah Islam masih dapat dikendalikan oleh seorang khalifah karena masih dalam konteks federal. Kemudian terjadi pelemahan kekuasaan di beberapa wilayah seperti wilayah Andalusia, Afrika Utara, sehingga kemudian terjadi perpecahan yang mengakibatkan aksi gerakan pemisahan dan kemerdekaan seperti yang terjadi di wilayah kekuasaan Umawiyah di Andalusia, dan wilayah kekuasaan Fatimiyah di Magrib dan Mesir. Sementara wilayah yang indevenden tetap berdiri di atas kekuatannya sendiri dan menjaga kedaulatannya sendiri baik dari dalam maupun dari luar, kendati mereka tetap menjalin komunikasi politik dengan pusat pemerintahan Dinasti Abbasiyah termasuk dalam masalah pengangkatan pejabat. Tidak dapat dipungkiri bahwa memang ada beberapa wilayah kekuasaan yang betul-betul memutuskan hubungan dengan khilafah Abbasiyah seperti negeri Attahiriyyah, negeri Assamaniyyah, negeri Buwaihiyyah, negeri Tuluniyyah, dan negeri Ihksyidiyyah. ${ }^{39}$

Walau beberapa negeri yang disebutkan terakhir tadi telah memutuskan hubungan dengan pusat khilafah Abbasiyah, tetapi mereka semuanya tetap diikat oleh akidah yang satu, tujuan yang sama, dan tetap terjalin hubungan kerjasama dalam hal kebajikan. Hubungan wilayah-wilayah tersebut bagaikan hubungan negara-negara serikat dalam konteks sekarang. ${ }^{40}$ Sedangkan pada masa

\footnotetext{
${ }^{37}$ Muhammad Ra'fat Usman, Riyasah Addaulah fi al-Fikhi al-Islami, Dar al-Kitab alJami'iy, Kairo, hlm.159.

${ }^{38}$ Hamid Sultan, 1970, Ahkam al-Qanun Addauliy fi Assyariah al-Islamiyah,Tab'ah alQahirah, Kairo, hlm. 110.

${ }^{39}$ Muhammad Ra'fat Usman, Riyasah Addaulah..hlm. 160.

${ }^{40}$ Muhammad Ra'fat Usman, Riyasah Addaulah..hlm. 161.
} 
pemerintahan Dinasti Utsmaniyah, dunia Islam dapat disatukan secara politik. Dan kekuasaan Dinasti Utsmaniyah dapat dikendalikan oleh pemerintah pusat sampai akhir abad ke 17 M. kemudian setelah itu mulailah Dinasti Utsmaniyah melemah karena beberapa sebab antara lain: ${ }^{41}$ (1). Lemahnya para penguasa pemerintah Utsmaniyah; (2) Terjadinya pelemahan di kalangan tentara dan pasukan pemerintah Utsmaniyah; (3) Kurangnya perhatian pemerintah pusat terhadap wilayah kekuasaannya terutama wilayah yang berada jauh dari pemerintah pusat; (4) Banyaknya terjadi kekacauan dan peperangan; (5) Lemahnya lembaga dan sistem pendidikan; (6) Lemahnya lembaga adiministrasi yang ada.

Apa yang telah disinggung sebenarnya telah dijelaskan secara mendalam oleh para ulama dari generasi ke genarasi yang kesemuanya menyatakan bahwa Islam adalah agama yang tidak hanya menyorot masalah akhirat saja tetapi juga tentang bagaimana berbangsa dan bernegara yang didasari dengan nilai-nilai toleransi, keadilan dan kesejahteraan. Semua itu dapat dilihat dalam karya-karya para ulama Islam seperti Abdul Jabbar al-Mu'tazliy $(415 \mathrm{H})$, Abul Hasan alMawardi (450 H), Ibnu Hazm Azzahiri (456 H), Abu Ya'la al-Farra' (458 H), Imam al-Haramain al-Juwaini $(478 \mathrm{H})$, Abu Hamid al-Gazali $(505 \mathrm{H})$, Umar bin Muhammad Annasafi (537 H), Abdul Karim Assaharstani (548 H), Fakhruddin Arrazi (606 H), Muhyiddin Annawawi (676 H), Ibnu Taimiyah (728 H), Adaduddin al-Ijiy (756 H), Saaduddin Attaftazani (792 H), Assayyid Syarif alJurjani (816 H), Izzuddin Ibnu Jamaah (819 H), al-Qalqasyandi (821 H), al-Kamal Ibnu al-Humam $(861 \mathrm{H})$, al-Kamal bin Abi Syarief $(905 \mathrm{H})$, dan sebagainya. ${ }^{42}$

Kebenaran yang diungkapkan di atas ternyata diamini banyak kalangan di barat termasuk oleh para orientalis. Berikut pernyataan mereka terkait dengan ajaran Islam dan posisi Nabi yang sesungguhnya: ${ }^{43}$

${ }^{41}$ Majdah Makhluf, 2000, Al-Khilafah fi Khitabi Attaturk, Dar al-Afak al-Arabiah, Kairo), hlm.17-18. Lihat juga Muhammad Ra'fat Usman, Riyasah Addaulah..hlm.161.

${ }^{42}$ Muhammad Ra'fat Usman, Riyasah Addaulah ...h.b, c.

${ }^{43}$ Muhammad Diyauddin Arrais, Annazariyat al-Siyasiyah al-Islamiyah, Maktabah Dar Atturats, Kairo, hlm.28-29. 
- Sir T. Arnold mengatakan: Muhammad adalah pemimpin agama sekaligus sebagai pemimpin negara.

- C. A. Nallino seorang orientalis berkebangsaan Italia mengatakan: Muhammad pada waktu yang bersamaan telah berhasil membangun agama dan negara, aturan serta batasan-batasannya sangat sesuai sepanjang hidupnya.

- R. Strothmann mengatakan: Islam adalah agama dan politik, karena penggagasnya adalah seorang Nabi, seorang pemimpin yang sangat ideal dan mengerti tentang tata-cara pemerintahan.

- D. B. Macdonald mengatakan: di Madinah telah berdiri negara Islam yang pertama, dan telah diletakkan dasar-dasar hukum Islam.

- Dr. V. Fitzgerald mengatakan: Islam bukan hanya agama, tetapi juga sebagai sistem politik. Kendati belakangan ini -menurutnya- muncul sebagian orang Islam yang mengklaim dirinya sebagai modernis yang mencoba memisahkan antara keduanya (agama dengan politik), tetapi suara pemikiran Islam kesemuanya terbentuk atas dasar bahwa keduanya tidak akan mungkin dapat dipisahkan.

- Dr. Schacht mengatakan: Islam lebih dari sekedar agama. Islam merupakan teori hukum dan politik. Islam adalah suatu sistem yang meliputi agama dan negara sekaligus.

- H.A.R. Gibb mengatakan: Islam bukan hanya sekedar akidah agama, tetapi juga telah menuntut pembentukan masyarakat yang hidupnya bersifat indevenden yang memiliki aturan dan sistem sendiri terutama dalam hal pemerintahan. $^{44}$

\section{B. Bela Negara dan Cinta Tanah Air di Dalam Islam}

Dalam Islam, masalah tanah air (alwatan) telah banyak dijelaskan yang intinya menanamkan dalam diri setiap manusia agar mencintai tanah airnya, bahkan harus membelanya jika ada yang mencoba mendudukinya. Olehnya itu,

\footnotetext{
${ }^{44}$ Muhammad Bahauddin Salim, Al-Islam, Addin, Addaulah...hlm. 42.
} 
makna tanah air tidak hanya sebatas pada wilayah atau tanah, tetapi juga meliputi bangsa, peradaban, sejarah, lembaga, kemenangan dan sebagainya. Addinawariy dalam kitab monumentalnya al-mujalasah wajawahiru al-ilmi meriwayatkan sebuah kisah dari al-Asmaiy yang mengatakan: aku pernah mendengar seorang a'rabiy mengatakan: jikalau engkau ingin mengetahui seorang lelaki yang sesungguhnya, maka lihatlah sejauhmana ia mencintai tanah airnya. ${ }^{45}$

Imam Fakhruddin Arrazi ketika berbicara tentang cinta tanah air beliau berdalil dengan beberapa ayat al-Qur'an. Ketika menafsirkan firman Allah dalam surah Annisa ayat 66 yang berbunyi:

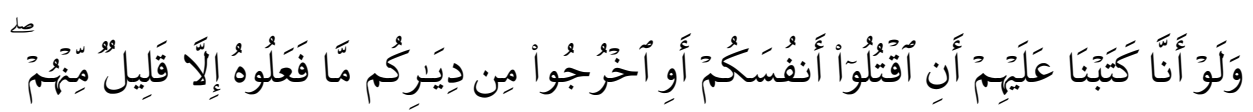

"Dan Sesungguhnya kalau kami perintahkan kepada mereka: "Bunuhlah dirimu atau keluarlah kamu dari kampungmu", niscaya mereka tidak akan melakukannya kecuali sebagian kecil dari mereka”. (QS. Annisa: 66).

Arrazi mengatakan bahwa dalam ayat tersebut, Allah menjadikan/menyamakan antara meninggalkan kampung halaman dengan membunuh diri sendiri. ${ }^{46}$ Allah SWT seakan-akan mengatakan: seandainya Aku menentukan dua hal yang sangat sulit bagi manusia maka mereka pasti tidak akan melakukannya. Dua hal yang sangat sulit itu adalah bunuh diri dan meninggalkan kampung halaman. Sedihnya perasaan meninggalkan kampung halaman sama persis dengan sakitnya bunuh diri. Oleh karenanya, cinta tanah air merupakan hal yang cukup dalam pengaruhnya terhadap diri setiap insan, sehingga ada ulama mengatakan bahwa meninggalkan kampung halaman adalah cobaan yang paling besar. $^{47}$

Bela negara dan cinta tanah air tidak hanya digambarkan oleh al-Qur'an, tetapi juga dalam hadis banyak diceritakan tentang cinta Nabi kepada tanah airnya. Imam Bukhari, Ibnu Hibban, dan Tirmizi meriwayatkan hadis dari Anas

45 Ahmad bin Marwan Addinawariy,2002, al-Mujalasah wajahiru al-Ilmi, Dar Ibni Hazm, Bairul Jld.1.hlm. 60 .

46 Fakhruddin Arrazi, 1489, Attafsir al-Kabir, Dar Ihya Atturats al-Arabiy, Kairo Jld.1.hlm. 1489.

${ }^{47}$ Usamah Assayyid Mahmud al-Azhariy, 2015, Al-Hakku al-Mubin, Dar al-Fakih, Abu dabi, hlm .171. 
bin Malik bahwa Nabi SAW ketika kembali dari perjalanan keluar kota; dan ketika beliau sudah melihat dinding-dinding kota Madinah, beliau menghentikan sejenak untanya; dan jika seandainya beliau sedang di atas untanya maka ia pun menggerakkannya sebagai pertanda cintanya kepada Madinah. Ibnu Hajar menjelaskan bahwa hadis tersebut menerangkan kalau kota Madinah memiliki banyak keistimewaan. Selain itu hadis tersebut juga menunjukkan pentingnya cinta tanah air dan rasa rindu kepadanya. ${ }^{48}$ Imam Badruddin al-Aiyni dalam umdatu al-qari', syarhu sahihi al-bukhari juga mengatakan hal serupa. ${ }^{49}$

Bahkan para ulama menjadikan cinta tanah air sebagai sebab (illat) sulitnya suatu "perjalanan" sehingga ada sebagian ulama menjelaskan tentang maksud dan makna hadis yang diriwayatkan Imam Ahmad dan Imam Tabrani dari Ukbah bin Amir, Nabi bersabda: "tiga golongan yang akan diterima doanya oleh Allah, doa orang tua untuk anaknya, doa orang yang sedang melakukan perjalanan (musafir), dan doa orang yang dizalimi atas yang menzaliminya". Para ulama menjelaskan bahwa sebab diterimanya doa orang musafir ialah karena ia sedang merasakan penderitaan, kesusahan, keterpaksaan, dan adanya rasa sedih disebabkan karena ia meninggalkan keluarga dan kampung halamannya. Imam alManawi mengatakan dalam kitab faedu al-Qadir, ketika mengomentari hadis tersebut di atas: "karena melakukan perjalanan merupakan sebab adanya kesedihan mendalam dalam diri seseorang disebabkan lamanya dalam keterasingan serta jauhnya dari tanah air. Sementara menanggung beban berat dan kesedihan berkepanjangan yang dirasakan adalah sebab utama dikabulkannya doa seseorang oleh Allah SWT. ${ }^{50}$

Allah SWT menciptakan setiap mahluk-Nya sesuai dengan fitrah dan kodratnya masing-masing. Hal yang menarik dari penciptaan itu ialah bahwa semua mahluk baik manusia maupun hewan kesemuanya diberi naluri untuk senantiasa condong kepada tempat hidupnya masing-masing. Bila merenungi lebih dalam ternyata semua mahluk memiliki naluri untuk menjaga dan mencintai tempatnya. Seekor singa, unta, semut, burung dan binatang lainnya memiliki

\footnotetext{
${ }^{48}$ Ibnu Hajar al-Askalani, Fathu al-Bari', Dar al-Ma'rifah, Bairut, Jld.3.hlm..261.

${ }^{49}$ Badruddin al-Ainiy, Umdatu al-Qari', (Maktabah Syamilah) Jld.15.hlm. 439.

${ }^{50}$ Al-Manawi, 1994, Faidu al-Qadir, Dar al-Kutub al-Ilmiyah, Bairut, Jld.3.hlm. .537.
} 
kecenderungan dan naluri cinta kepada tempat tinggalnya. ${ }^{51}$ Dalam beberapa referensi disebutkan bahwa Rabiah al-Basriy menulis satu buku yang diberi judul 'Haninu al-Ibli Ila al-Authan yang maknanya adalah "kerinduan seekor unta kepada tanah airnya/tempat tinggalnya". 52

Kalau saja rasa rindu dan cinta tempat tinggal dapat dirasakan oleh binatang, maka terlebih lagi manusia. Oleh karenanya tidak berlebihan jika kemudian Ibnu al-Jauzi mengatakan: 'tanah air selamanya akan dicintai'. ${ }^{53}$ Imam al-Qarafi seorang ulama fikih mazhab Maliki mengomentari tentang hikmah ibadah haji dengan ganjaran pahala yang besar yang didapatkan seorang yang berhaji karena ibadah haji dapat mendidik hati seseorang serta membuatnya lebih sabar untuk meninggalkan kampung halamannya. ${ }^{54}$

Dalam sejarah banyak disebutkan sosok ulama Islam yang begitu cinta terhadap tanah airnya. Imam Abu Nuaim menyebutkan bahwa Ibrahim bin Adham pernah mengatakan: "aku tidak meninggalkan sesuatu yang begitu berat bagiku daripada meninggalkan tanah air", 55 Banyaknya karya para ulama Islam sepanjang sejarah terkait dengan pentingnya bela negara dan cinta tanah air merupakan bukti kuat bahwa Islam secara implisit adalah agama dan negara.

Berikut beberapa karya ulama yang mengulas secara spesifik tentang bela negara dan cinta tanah air: ${ }^{56}$

1- Hubbu al-Wathan karya al-Jahiz. ${ }^{57}$

2- Al-Hanin Ila al-Awthan karya al-Qhadi Shaleh bin Ja'far bin Abdul Wahhab al-Hasyimi seperti yang dijelaskan oleh Imam Ibnu Asakir dalam karya monumentalnya: "Tarikh Dimasyk".

3- Assyauku Ila al-Awthan karya Abu Hatim Sahal bin Muhammad Assijistani.

\footnotetext{
${ }^{51}$ Usamah Assayyid Mahmud al-Azhariy, Al-Hakku al-Mubin ...hlm. 174.

${ }^{52}$ Usamah Assayyid Mahmud al-Azhariy, Al-Hakku al-Mubin ...hlm. 175.

${ }^{53}$ Ibnu al-Jauzi, 1995, Mutsir al-Garam al-Sakin ila Asyrafi al-Amakin, Dar al-Hadis, Kairo, hlm.75.

${ }_{54}$ Syihabuddin Ahmad bin Idris al-Qarafi, al-Tsakhirah, Dar al-Garb, Bairut, Jld.3.hlm.194.

${ }_{55}^{55}$ Abu Nuaim, Hilyatu al-Auliyai, Dar al-Kitab al-Arabiy, Bairut, Jld.7.hlm.380.

${ }^{56}$ Usamah Assayyid Mahmud al-Azhariy, Al-Hakku al-Mubin ...hlm. 179.

${ }^{57}$ Buku tersebut dicetak oleh Dar Arraid al-Arabiy, Bairut pada tahun 1982, dengan judul: al-Hanin ila al-Authan.
} 
4- Al-Hanin Ila al-Awthan karya Abu Hayyan Ali bin Muhammad Attauhidi.

5- Al-Manahilu wal A'than, wal Haninu Ila al-Authan karya Abu Muhammad al-Hasan bin Abdurrahman bin Khallad.

6- Mukawwamat Hubbi al-Wathan fi Daui Ta'alimi al-Islam karya Doktor Sulaiman bin Abdullah bin Hammud Aba al-Khalil.

7- Hubbu al-Wathan min Manzurin Syar'iyyin karya Doktor Zaid bin Abdul Karim Azzaid.

8- Al-Wathan wa al-Istiythan, Dirasah Fikhiyyah karya Doktor Muhammad bin Musa bin Mustafa Addaliy.

\section{PENUTUP}

Didalam Islam, sudah menjadi konvensi bahwa antara shalat dan puasa tidak mungkin dapat dipisahkan, antara syiar agama dan suatu sistem politik. Oleh karenanya, di dalam Islam dinyatakan tidak boleh ada partai politik yang dibentuk untuk mengajak orang banyak untuk memisahkan antara agama dan negara. Di dalam Islam tidak diperkenankan adanya partai yang visi misinya membedakan antara persoalan ibadah dengan persoalan muamalah. Itulah mengapa di dalam sejarah Islam, sekte-sekte yang muncul misalnya Khawarij, Syiah dan kelompok ahlussunnah yang moderat walau mereka berbeda dalam masalah dosa besar dan dosa kecil, berbeda dalam hal tertentu lainnya yang mengakibatkan terjadinya perseteruan yang berkepanjangan, tetapi di lain sisi mereka semuanya sepakat bahwa agama Islam bersifat universal mencakup semua sendi kehidupan manusia.

Manusia tidak akan dibiarkan oleh agama untuk menyelesaikan masalah mereka sendiri seperti halnya yang dikatakan oleh para kaum materialis. Begitu juga mereka tidak akan diselesaikan masalahnya oleh ilmu pengetahuan semata seperti yang dikatakan oleh para ilmuan yang memandang ilmu sebagai sesuatu yang selalu berkembang. Sehebat apapun yang telah dicapai oleh para ilmuan dan kelompok materialistis tidak akan pernah dapat menyelesaikan masalah mereka bila agama tidak dilibatkan di dalamnya. Buktinya dengan majunya ilmu pengetahuan, manusia tidak henti-hentinya saling memusuhi antara satu dengan yang lain, bahkan saling membunuh dan menghancurkan hanya karena persoalan 
materi, kekuasaan dan berbagai macam kepentingan lainnya. Olehnya itu maka islam itu secara implisit adalah agama dan negara.

\section{DAFTAR PUSTAKA}

Abdussalam, Faruq, Al-Ahzab al-Siyasiyah wal Faslu Baina Addini Wassiyasah, Maktabah Kalyub, Kairo

Addinawariy, Ahmad bin Marwan, 2002, al-Mujalasah wajahiru al-Ilmi, Jld 1. Dar Ibni Hazm, Bairut.

Al-Asqalani, Ibnu Hajar, Fathu al-Bari', Jld 3. Dar al-Ma'rifah, Bairut,

Al-Azhariy, Usamah Assayyid Mahmud, 2015, Al-Hakku al-Mubin, Dar al-Fakih, Abu dabi.

Al-Bahiy, Muhammad, 1980, Addin wa Addaulah, Maktabah Wahbah, Kair

Al-Ghazali, Abu Hamid , Al-Wasit fi al-Mazhab, Jld. 7 Dar Assalam, Kairo

Al-Hushary, Ahmad, Addaulatu Wasiyasatu al-Hukmi fi al-Fikhi al-Islami, Maktabah al-Kulliyat al-Azhariyah, Kairo

Al-Jauzi, Ibnu, 1995, Mutsir al-Garam al-Sakin ila Asyrafi al-Amakin, Dar alHadis, Kairo.

Allafi, Muhammad, Nazarat fi Ahkami al-Harbi wa Assilmi, Dar Iqra, Libia Al-Manawi, 1994, Faidu al-Qadir, Jld. Dar al-Kutub al-Ilmiyah, Bairut.

Al-Maududi, Abul A'la, 1985, Nazariyah al-Islam wa Hadyuhu fi Assiyasah Walqanun Waddustur, Addar Assaudiyah, Jeddah

Al-Mawardi, Abul Hasan , Adabu Addun-ya wa Addin, Tab'ah al-Kahirah, Kairo Andrae, Tor ,1960, Muhammad, The Man and His Faith, New York

Al-Razi, Fakhruddin, 1489, Attafsir al-Kabir, Jld 1, Dar Ihya Atturats al-Arabiy, Kairo

Arrais, Muhammad Diyauddin, Annazariyat al-Siyasiyah al-Islamiyah, Maktabah Dar Atturats, Kairo.

Al-Qarafi, Syihabuddin Ahmad bin Idris, al-Tsakhirah, Jld.3, Dar al-Garb, Bairut Abu Nuaim, Hilyatu al-Auliyai, Jld.7. Dar al-Kitab al-Arabiy, Bairut

Attabrani, Abu Ja'far, Tarikh Attabari, Jld.2, Dar al-Ma'arif, Kairo

Attabrani, Sulaiman bin Ahmad, 1415 H, al-Mu'jam al-Aushat, Jld 8, Dar alHaramain, Kairo

Aziz. A. Gaffar, 2000, Berpolitik untuk Agama, Pustaka Pelajar, Yogyakarta

Azzabidi, Muhammad , Taj al-Arus, Jld IX, Dar Assadar, Bairut

Badawi, Ismail, 1994, Nazariyyah Addaulah, Dar Annahdah al-Arabiyah, Kairo

Hisyam, Ibnu , Assirah Annabawiyah, Jld.4, Dar Attahrir, Kairo

Makhluf, Majdah, 2000, Al-Khilafah fi Khitabi Attaturk, Dar al-Afak al-Arabiah, Kairo,

Muhammad Ra'fat Usman, Riyasah Addaulah fi al-Fikhi al-Islami, Dar al-Kitab al-Jami'iy, Kairo.

Musa, Muhammad Yusuf, 1995, al-Islam Wahajatul Insan Ilaihi, Wizarah alAukaf, Kairo

Salim, Muhammad Bahauddin, al-Islam, Addin, Addaulah, Kitab al-Jumhuriyah, Kairo 
Jurnal Al-adalah, Vol.3 No 2, Juli 2018 : 79-116

Sofyan, Ayi, 2012, Etika Politik Islam, Pustaka Setia, Bandung

Sultan, Hamid, 1970, Ahkam al-Qanun Addauliy fi Assyariah al-Islamiyah, Tab'ah al-Qahirah, Kairo

\section{Internet}

Mohammad Arifudin, http://ibnunahl09.blogspot.co.id/2012/06/. diakses 26 November 2016. 